العداد الثالث والأربعون

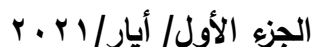

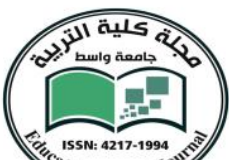

tion College

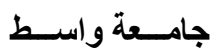

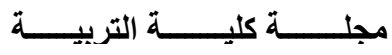

\title{
المهيمنات الأسلوبية في همزية الحطيئة
}

م.د. نضال حسيب فلفل الظالمي

جامعة واسط / كلية العلوم

\section{nahaseeb@uowasit.edu.iq}

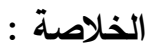

إنَّ همزيـة الحطيئة واحدة مـن قصـائد الثـعر العربي التي أخذت طابعاً متميزاً بمهيمناتها

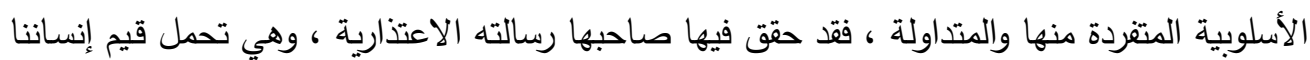

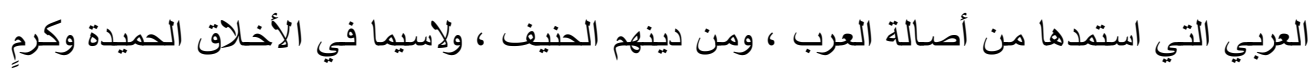

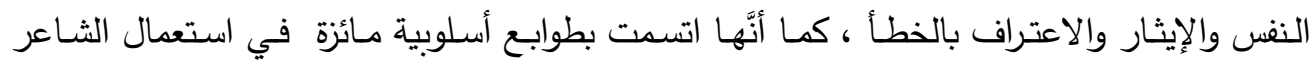

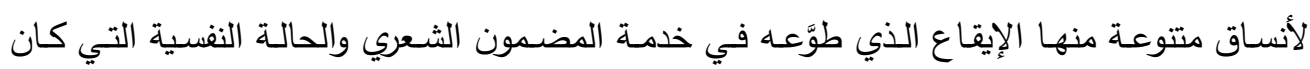

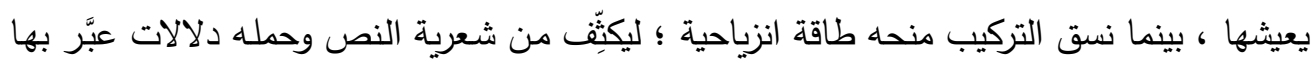

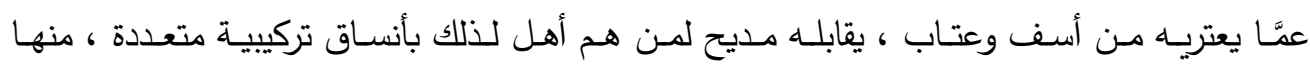

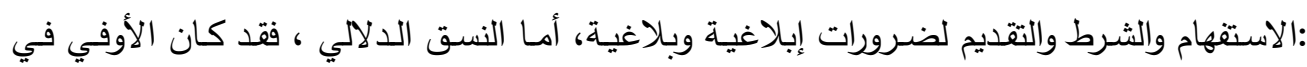

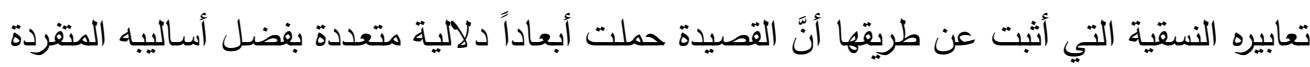

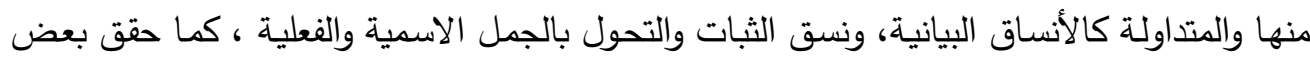

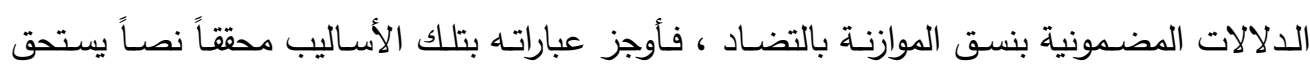
الدرس والقراءة .

الكلمات المفتاحية : النسق ، التفرد ، التداول . 


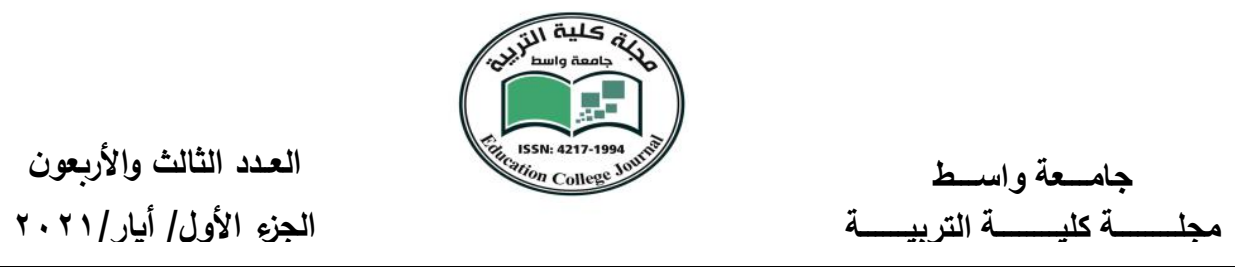

\title{
Stylistic dominions in Hamziah Al-Hateia
}

\author{
Dr. Nadhal haseeb fulful Al dihlimy \\ Colleg of sciences - wasit university \\ nahaseeb@uowasit.edu.iq
}

\begin{abstract}
:
Hamziah of al-Hateia is one of the poems of Arabic poetry that took on a distinct character with its unique and circulating stylistic dominions, in which its owner fulfilled his apologetic message, and it bears the values of our Arab people that he derived from the authenticity of the Arabs and their true religion, especially in good morals, self-generosity, altruism, and recognition of error.It was characterized by distinctive stylistic stamps in the poet's use of a variety of formats, including the rhythm that he used to serve the poetic content and the psychological state in which he lived, while coordinating the composition, it gave him a shifting energy. In order to intensify the poeticity of the text and carry its connotations that express the regret and reproach he is experiencing, he is matched by praise to those who are qualified for this in multiple synthetic formats, including: the interrogation, the condition and the presentation of informative and rhetorical necessities, and as for the semantic system, it was the most complete in his systemic expressions through which he proved that the poem carried Multiple semantic dimensions thanks to its unique and circulating methods such as the graphic formats, the consistency and transformation format in nominal and verbal sentences, and he also achieved some implicit connotations in the balancing format by contradiction, so he summarized his phrases with these methods, achieving in his unique style a text worth studying and reading
\end{abstract} Key words : Layout, Uniqueness, Deliberative 
العدد الثالث والأربعون

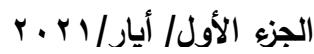

المقدمة

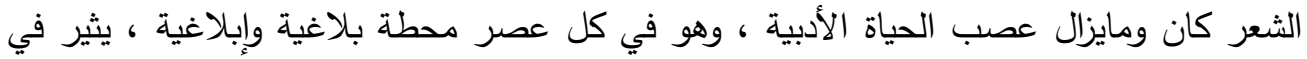

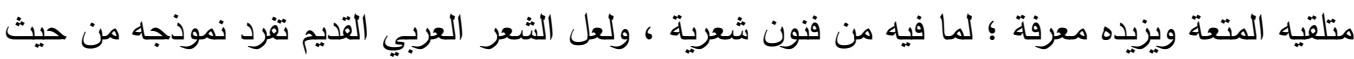

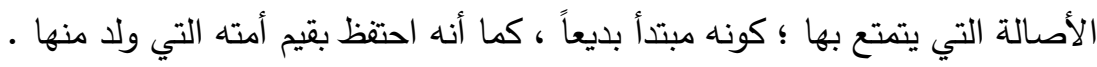

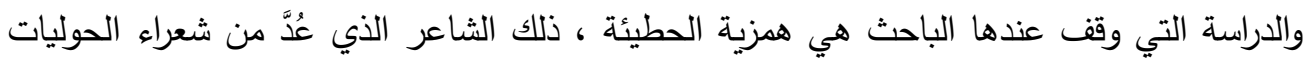

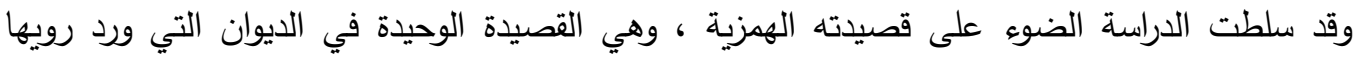

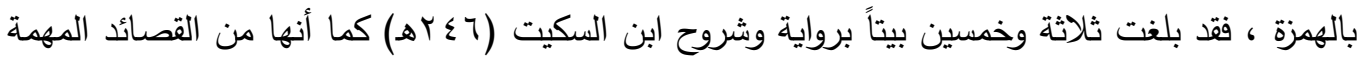

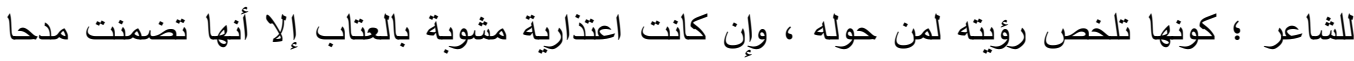

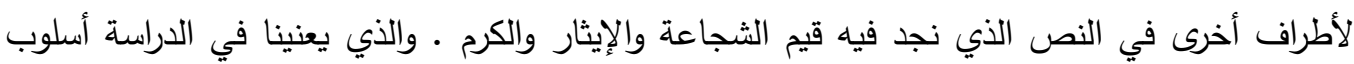

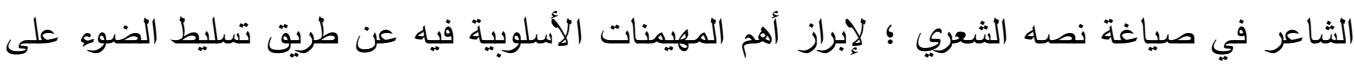

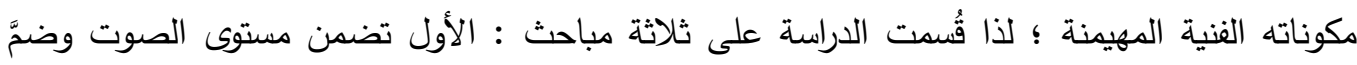

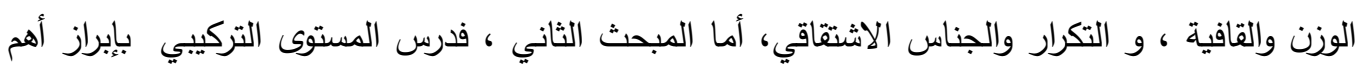

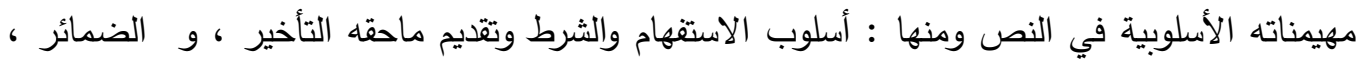

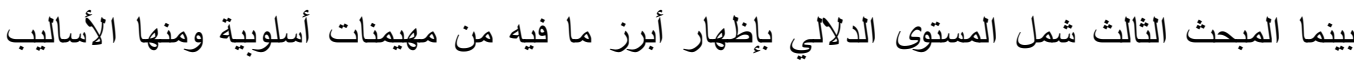

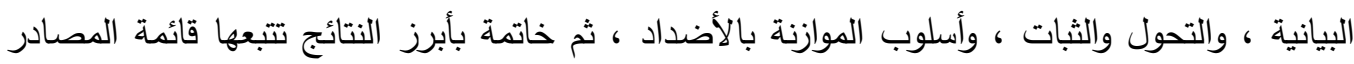

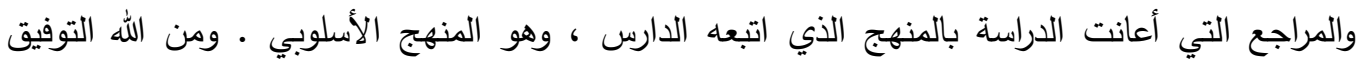
والسداد .

التمهيد

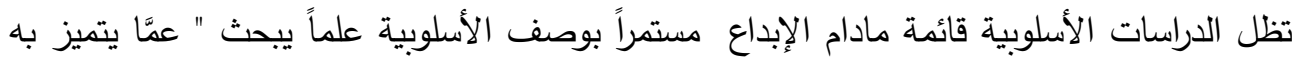

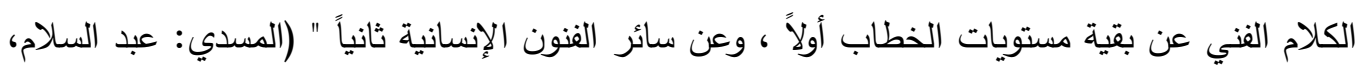

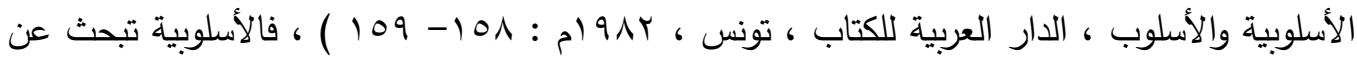

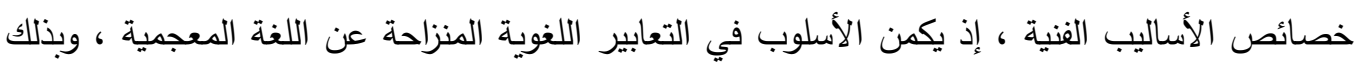

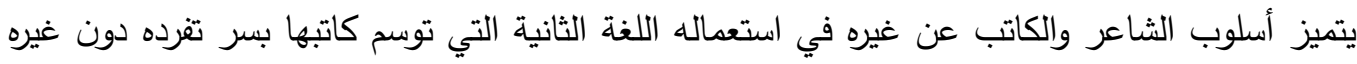

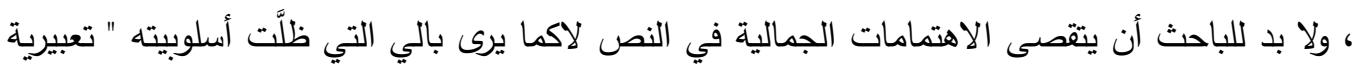

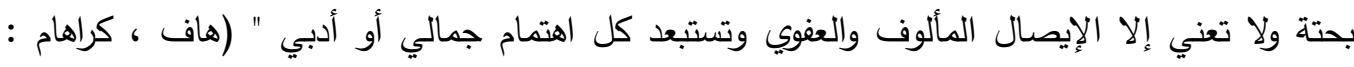

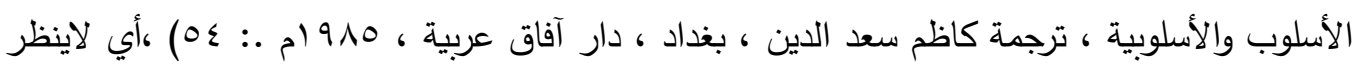

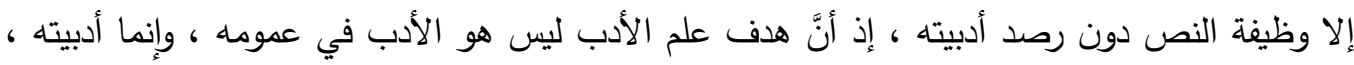


العدد الثالث والأربعون

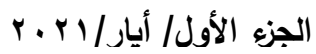

أي تلك العناصر المحددة التي تجعل منه عملاً أدبياً جميلاً، ولهذا فعلى الناقد الأدبي أن لايعنى إلا

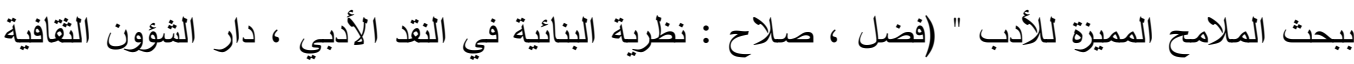

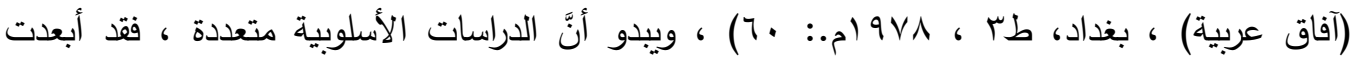

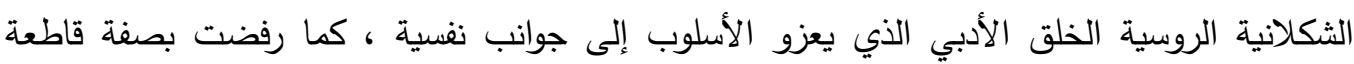

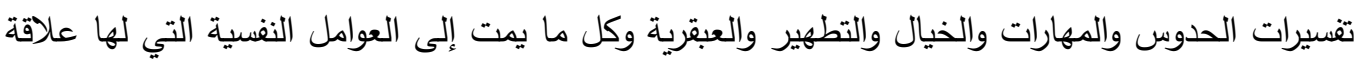

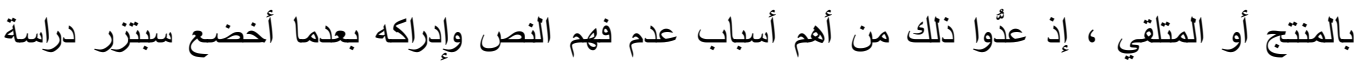

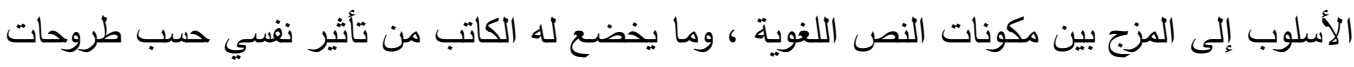

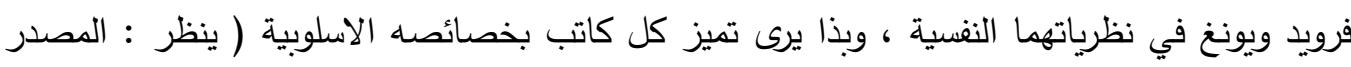

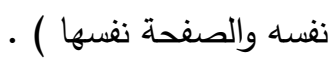
إنَّ دراسة الأسلوب قديمة قِدم البلاغة ، فقد "ارتبطت بالبلاغة وقواعدها المعيارية ، وكان هذا سبباً

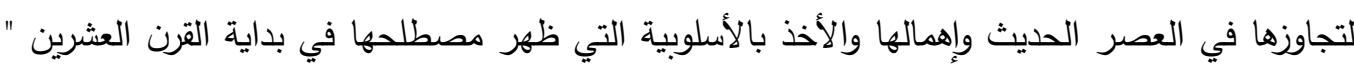

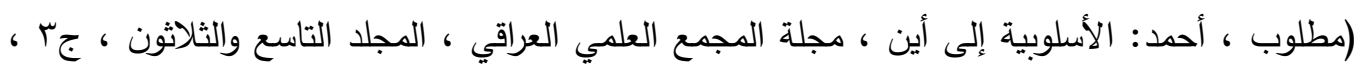

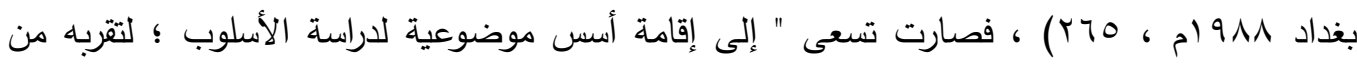

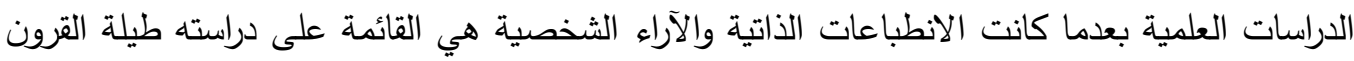

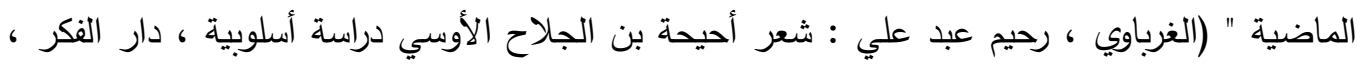

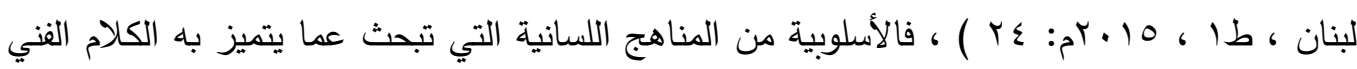

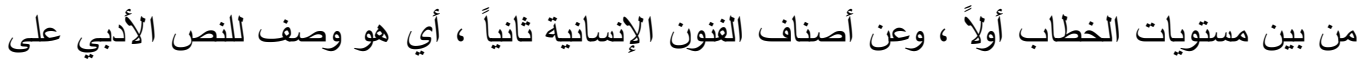

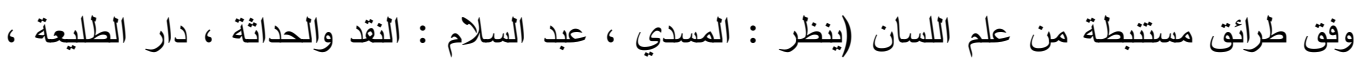

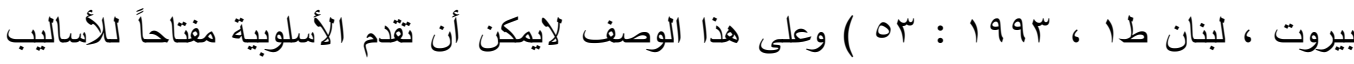

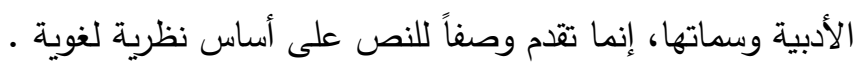

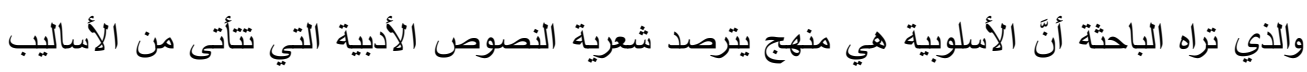

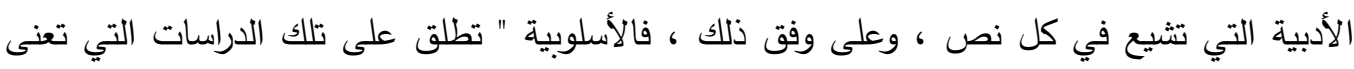

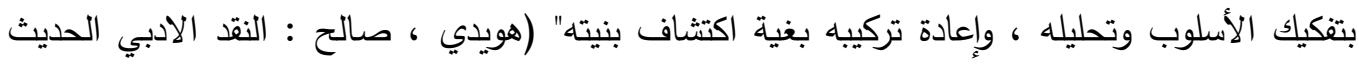

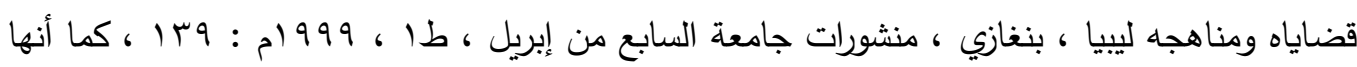

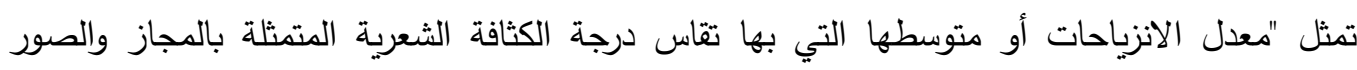

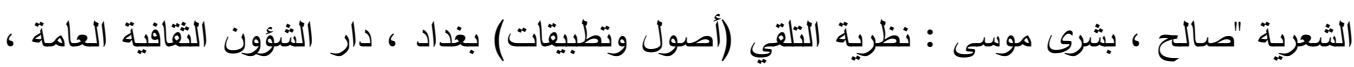


العدد الثالث والأربعون

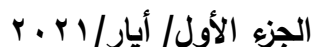

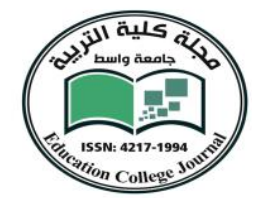

طا ، 999 199 : rی ، فالاسلوبية تدرس الجوانب الفنية للسمات الإبداعية التي تكسو النص جمالاً ،

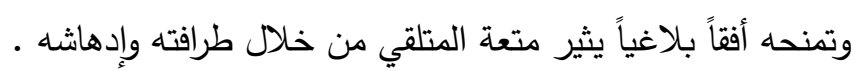

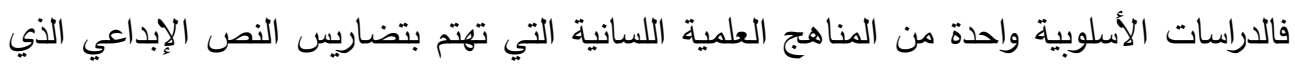

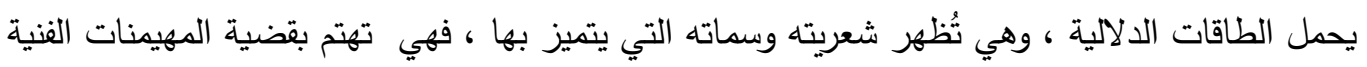

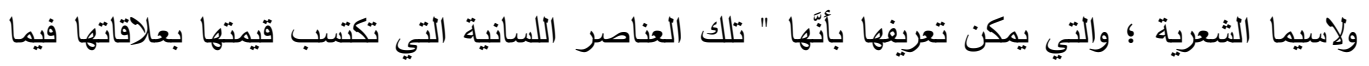

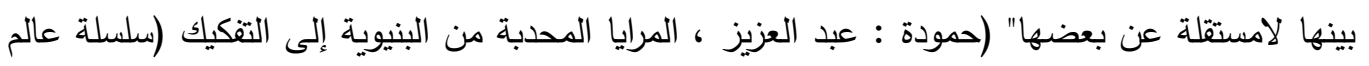

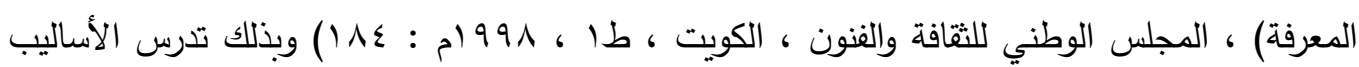

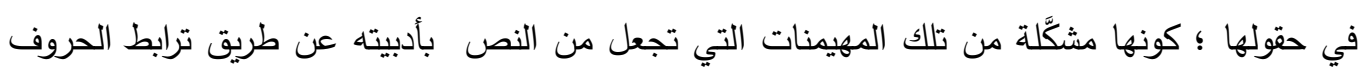

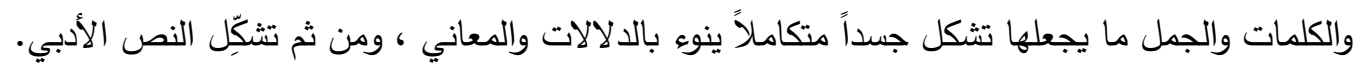

\section{المبحث الأول}

المستوى الصوتي

الصوت ركن من أركان الفن الثعري ، بوصف الفنون الثعرية جميعها تطمح في بناء نسيجها من

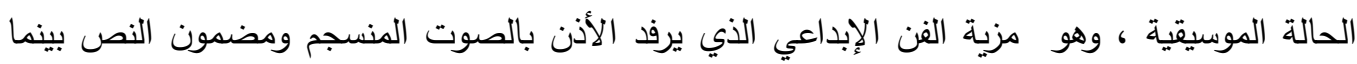

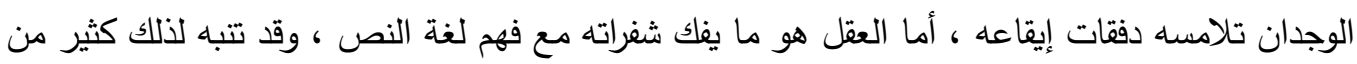
النقاد القدماء.

والإيقاع الثعري يضم ألفاظ الحروف والكلمات والتراكيب وانتظامها على وفق وقع معين ينسجم

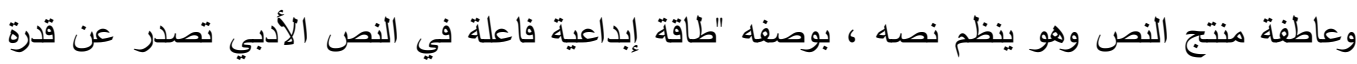

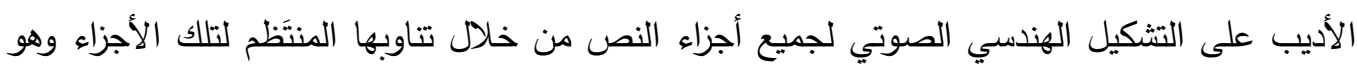

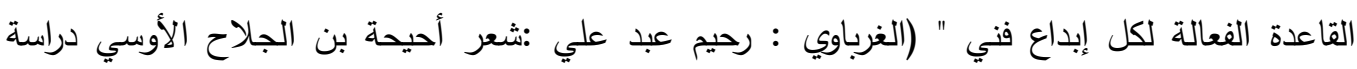

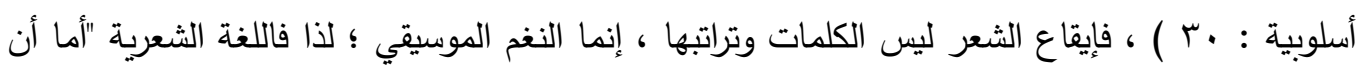

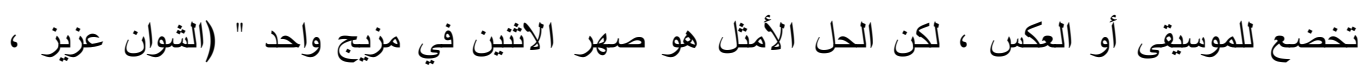

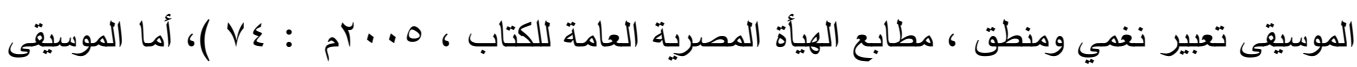

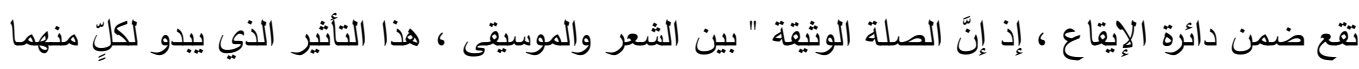

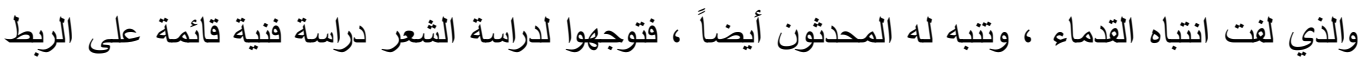

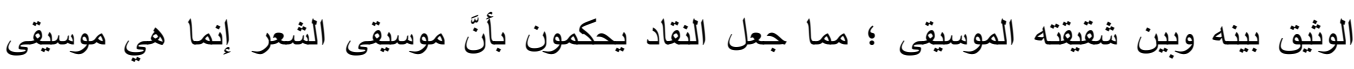

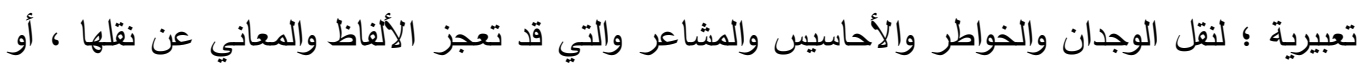


العدد الثالث والأربعون

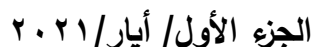

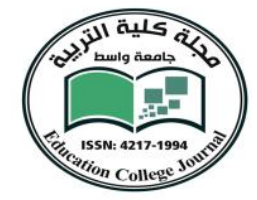

الإيحاء بها ، فتأتي الموسيقى رزاً دالاً موحياً على كل هذا " (نافع : عبد الفتاح صالح ، عضوية الموسيقى في النص الثعري ، مكتبة المنار ، الأردن ، طا ، 991 (1م :بr ).

والصوت في القصيدة يتمثل بالوزن والقافية والجناسات ، والتكرارات ، ومظاهر التقسيم • فالقصيدة هي من البحر الوافر ؛ لما له من سرعة في تفعيلاته التي يشترك فيها تعجله لنفسيته المضطربة والمتحمسة في آنٍ ؛ بغية إيصال رسالته إلى بني عوف بن كعب وهو يعتذر منهر ، ولعل طواعية البحر في زمّ البيت بالسرعة وبالارتخاء تبعا للعاطفة يجعل تعاور زحاف العصب على تفعيلة مفاعَلَتُن ، فتصير مفاعَلْنت(مفاعيلن)(الهاشمي أحمد : ميزان الذهب في صناعة شعر العرب ، مصر ، د ت : (1)؛ مما يمنح البيت سببين مترادفين ، هما ما يسارعان في حمل انفعالات الثاعر الهادرة ، وعلة القطف وهي إسقاط السبب الخفيف من مفاعلتن فتصير مفاعل ، فتتتقل إلى مفعولن ( ينظر : المصدر

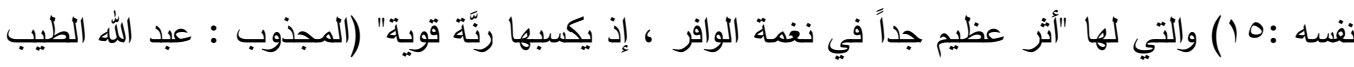

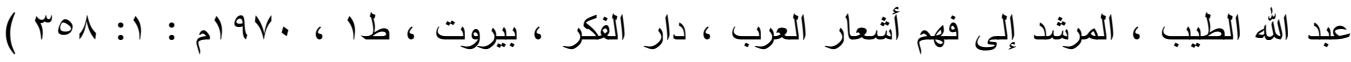
كومنه قول الثاعر في افتتاح قصيدته وهو يحمل أشد العاطفة (الحطيئة ، الديوان ، : اب) :

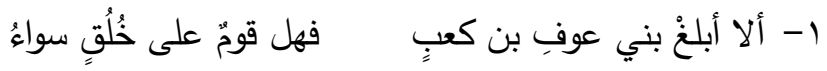

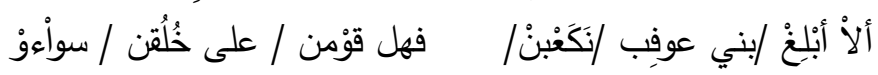

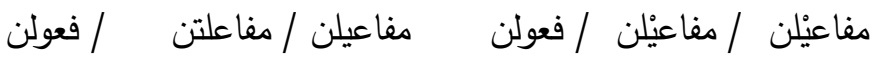
فالذي طرأ زحاف العصب والقطف في عروضه وضربه ؛ لجعل البيت متسارعاً مع سرعة الانفعالات التي دهمت الثاعر ؛ لأنه كان متعجلاً ؛ لإيصال رسالته في الاعتذار بينما في البيت التالي آثر الاسترخاء ؛ وذلك بذكر أسماء معطوفة على بني عوف وجملة خبرية في الثطر الثاني بقوله

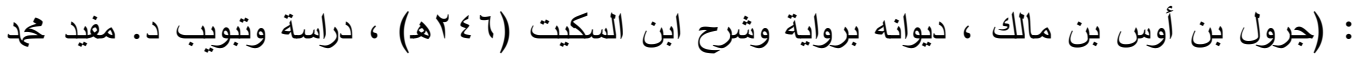

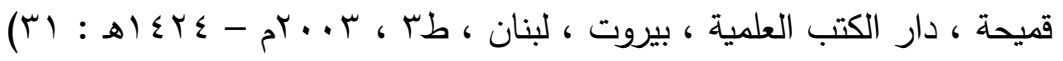

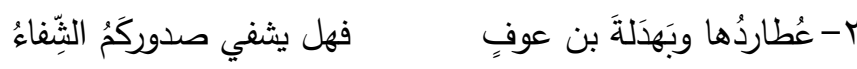

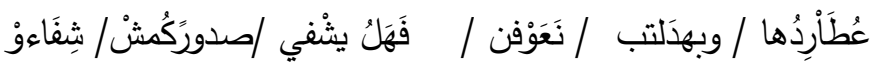

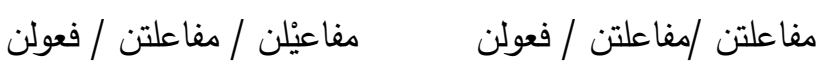
إذ نجد التفعيلات الصحيحة متفشية في البيت ، إذ لاحاجة فيها لتوتر الثاعر إلا في التفعيلة الأولى من عجز البيت (فهل يشفي) وهي تحمل معنى التعجب والإنكار . وحين يقرر في كلامه ، وكأنه يسائل نفسه ؛ ليعطي العذر نجده بحالة استرخاء على قدرٍ ما يحمله البحر في طبيعته التي تفشى فيها الإخبار ، يقول (الديوان : اسب) : 


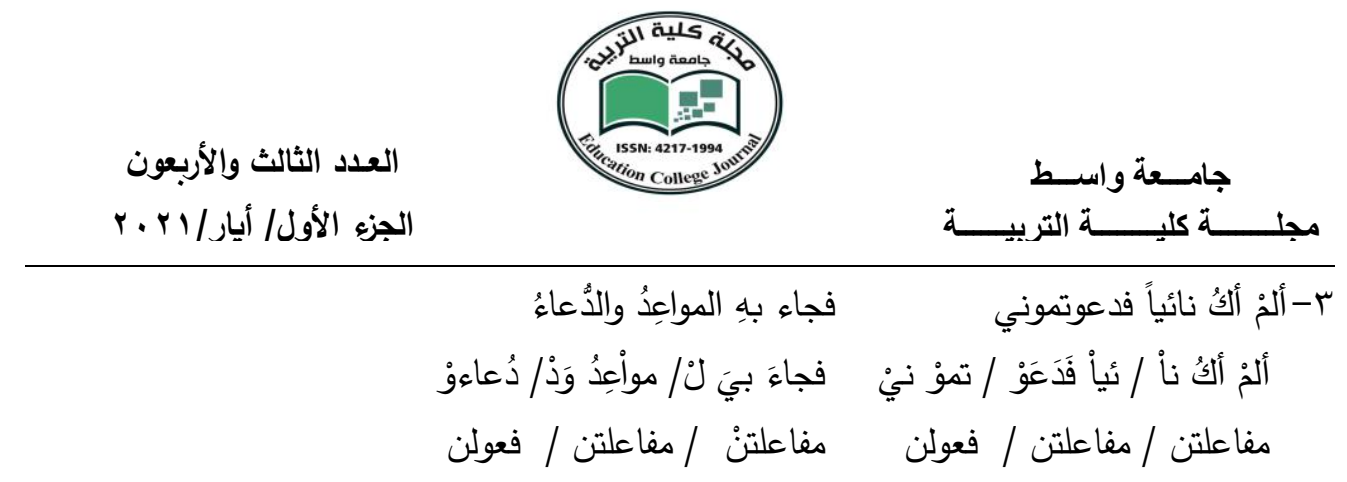

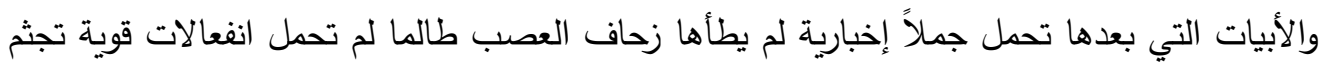

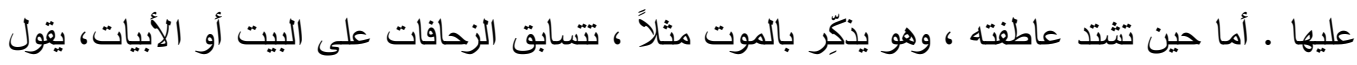

$$
\begin{aligned}
& \text { (الديوان : بr): } \\
& \text { فأفَنْتَدُ وليس لها فناءُ } \\
& \text { r }
\end{aligned}
$$

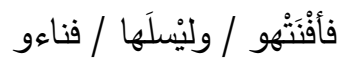

$$
\begin{aligned}
& \text { مفاعيلن / مفاعلتن / فعولن } \\
& \text { على رِنِبْ / مَنْونِ تدا / ولتهُو } \\
& \text { مفاعيلن / مفاعلتن/ فعولن }
\end{aligned}
$$

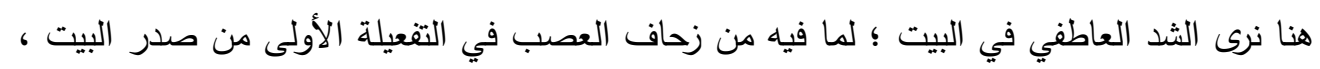

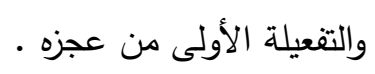

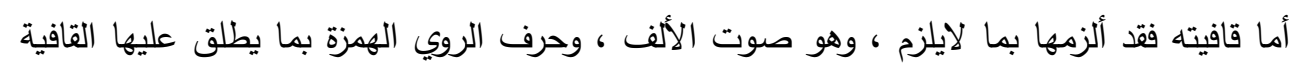

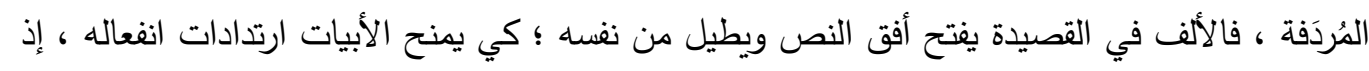

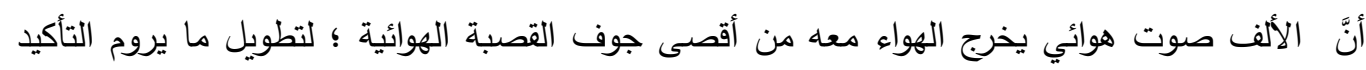

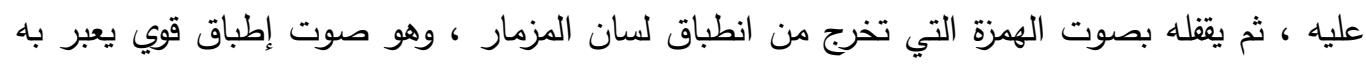

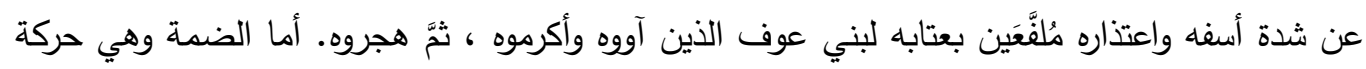

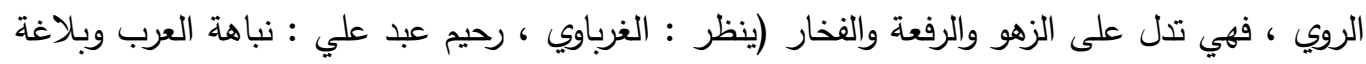

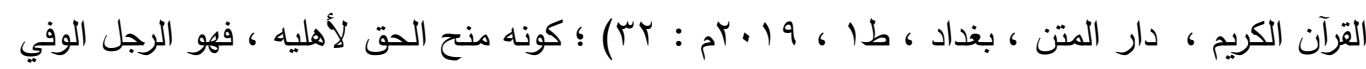

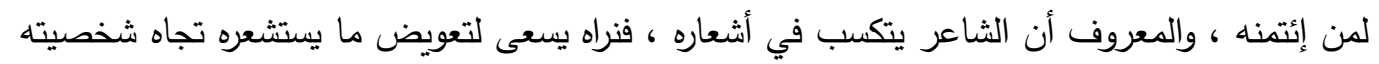

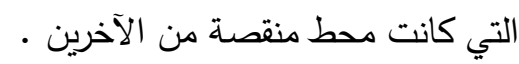
يتضح أنَّ أسلوب الثاعر يكمن في انتقائه البحر ؛ ليعبِّر به عن مدى النفعالاته تجاه قضاياه

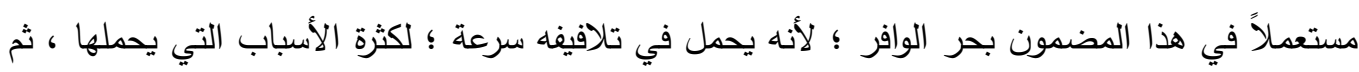

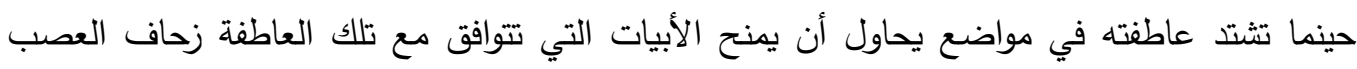

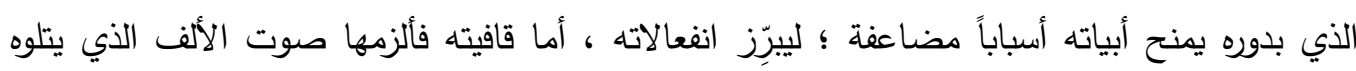

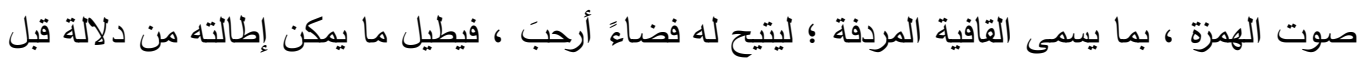
نهاية كل بيت يقفله بالهمزة وهي صوت إطباق شديد ؛ كي يجعل من إيقاع النص أكثر صخباً وأثد رنيناً 
العدد الثالث والأربعون

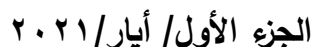

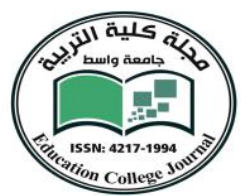

ولما كان الثعر هو الينبوع الدافق من الحروف والكلمات الذي يتأسس منها ، إذ أنَّ طبيعة الثعر تتأسس على موسيقى الألفاظ الرافدة للمعاني التي ينتظمها النغم ، وهي تتهادى مع موسيقى الأبيات مشكّلة بذلك إيقاع النص ، ولعل الحروف والألفاظ تُنظم بسلك فني متميز تصوغه قدرات الثاعر الفنية ولاسيما البناء الموسيقي الداخلي الذي يضاهي موسيقى النص الخارجية ، ويبدو أنَّ الحطيئة في قصيدته استطاع أن يمازج بين المضمون والانفعال والألفاظ التي منحها نغماً منسجماً مع ما يبوح به النص من كن

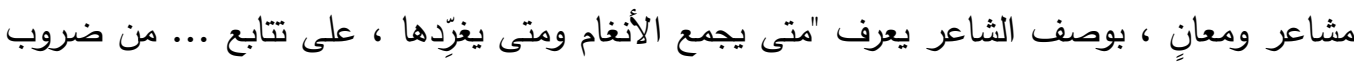
التأثير المختلفة عن طريق تسيق الأصوات والصور والتدرج بالعاطفة والانتقالات اللفظية المفاجئة ، وتصبح اللغة لديه ضرباً من الموسيقى تنبثق عن النغم والإيقاع واللحن " ( نافع : عبد الفتاح ، عضوية الموسيقى في النص الثعري مكتبة المنار ، الأردن ، طا ، 9919 ام : ب م) • ومن مظاهر الموسيقى

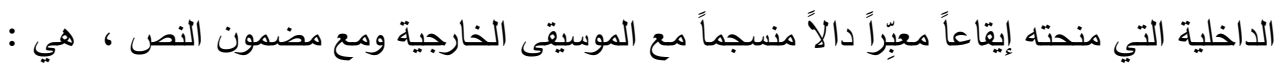
ا- التكرار : وهو ترديد صوتي للحروف أو الكلمات أو الجمل يستعمله المبدع حين يهتم بمعنيً ما يحاول التأكيد عليه من أجل إرساء تلك الفكرة في ذهن المتلقي ، كما أنه يزيد من جمال الإيقاع ، ولعل "كل تكرار مهما كان نوعه تستفاد منه زيادة النغم وتقوية الجرس" (المجدوب ، عبد الله الطيب ، المرشد إلى فهم أشعار العرب : Y / IV ( )، فالتكرار في طبيعته "يسلط الضوء على نقطة حساسة في العبارة ويكثف عن اهتمام المتكلم بها ، وهو بهذا ذو دلالة نفية قيمة " (الملائكة ، نازك ، قضايا الشعر

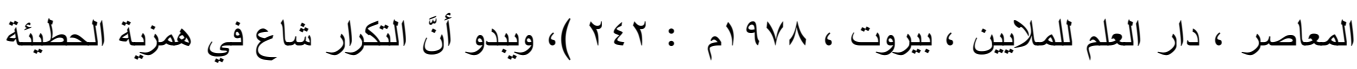
حتى شكَّلَ ظاهرة أسلوبية ، فهو يمنح النص نغماً موسيقياً بترديد الحروف والألفاظ والجمل ، إذ إنَّ الأذن العربية تحبب تكرار الألفاظ التي لا تتسجم ومكونات الإيقاع الأخرى ، فهو يدخل ضمن التوصيف بترديف اللاشعوري الذي يسلطه الشعر في أعماق الثاعر فيضيئها (ينظر :المصدر نفسه : بـ) . - تكرار الصوت : نجد الحطيئة يكرر بعض الأصوات في كل بيت ؛ ليعبر عن دفقه الثعوري كما أنه يدور حول بعض الأصوات التي تستمكن لاوعيه مستعملاً ألفاظاً تشتمل على تلك الأصوات ؛ مما يجعلها تتكرر لدواعٍ دلالية ، ومنه ما نجده في مطلع قصيدته التي يقول فيها (الديوان : (ب) :

$$
\begin{aligned}
& \text { ا- ألا أبلغ بني عوف بن كعبٍ فهلْ قومٌ على خلقٍ سـواءُ } \\
& \text { r- عطاردها وبهدلة بن عوفٍ فهل يشفي صدوركمُ الشفاءُ }
\end{aligned}
$$

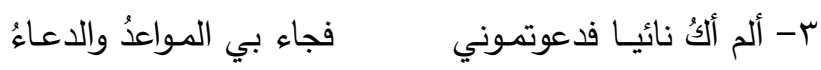

$$
\begin{aligned}
& \text { ع- ألم أكُ جاركم فتركتموني لكلبي في دياركٌُ عــواءُ } \\
& \text { 0- أجيل على الخباء ببطنِ قوٍّ نبات الليل فاحتُمِل الخبـاءُ }
\end{aligned}
$$


العدد الثالث والأربعون

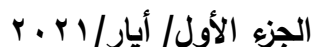

نجد تفشي صوت الباء في البيتين الأولين ، إذ كرره ست مرات ، وهو صوت إطباق شديد منح

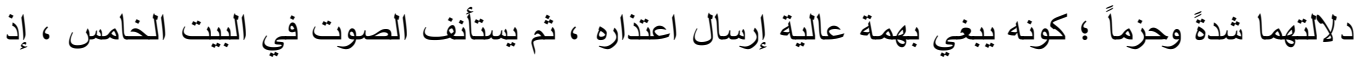

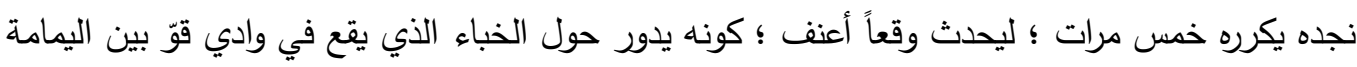

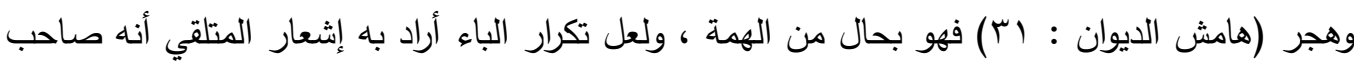

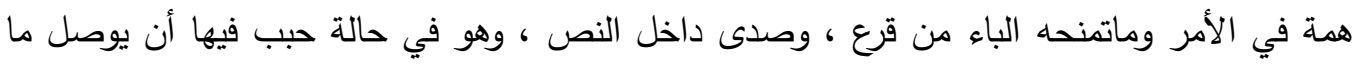

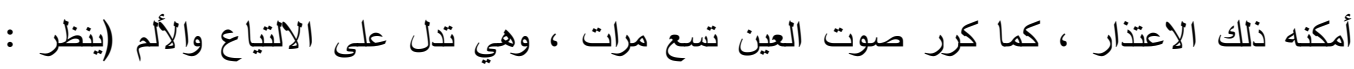

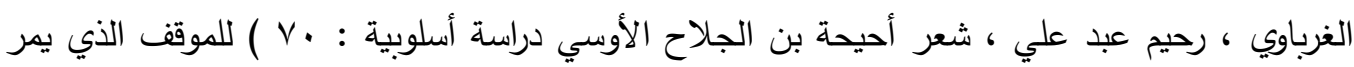

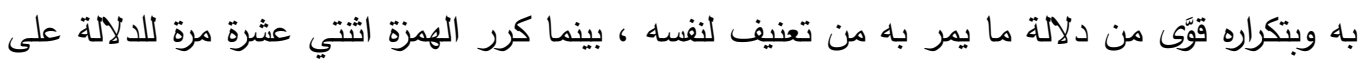

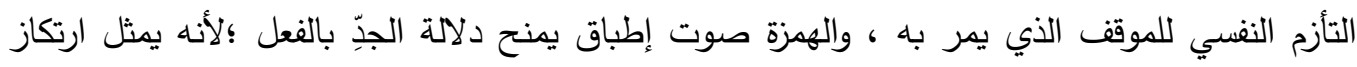

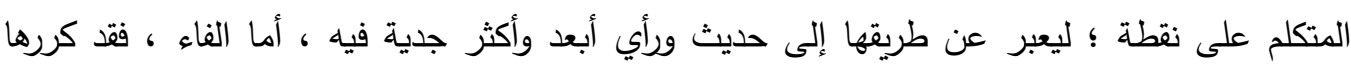

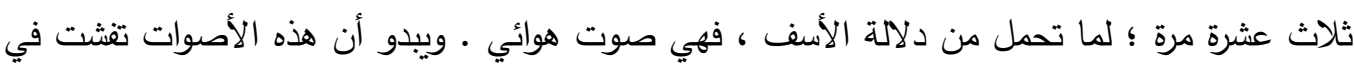

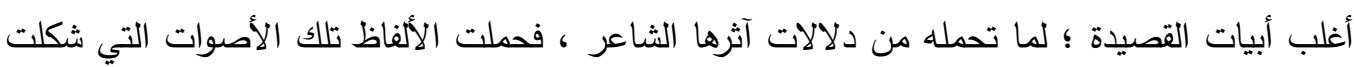

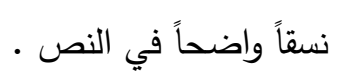

ويبدو أن تكرار الأصوات شكل ظاهرة أسلوبية في القصيدة ، وهي تحمل قرعاً نغمياً يعزز دلالة

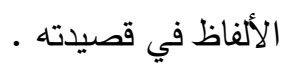
- تكرار الألفاظ : التكرار بالألفاظ شكَّل لاى الثاعر سمة أسلوبية مائزة ، فقد كرر الأسماء والضمائر

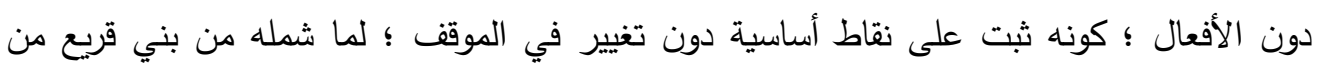

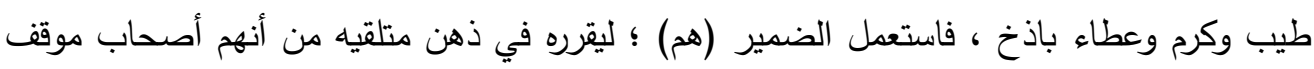

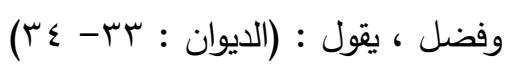

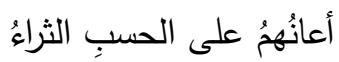

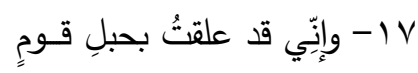

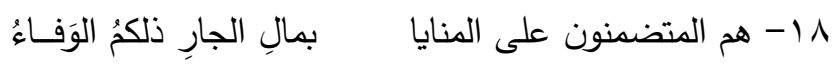

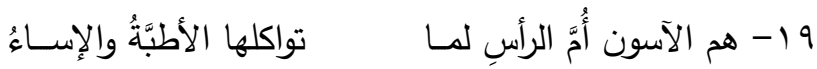

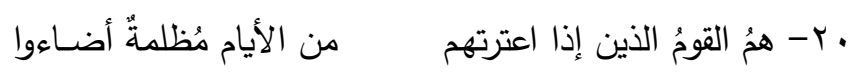

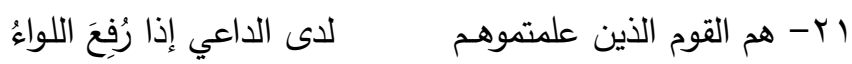

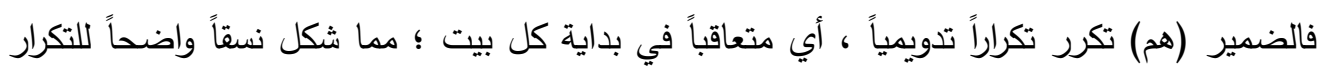

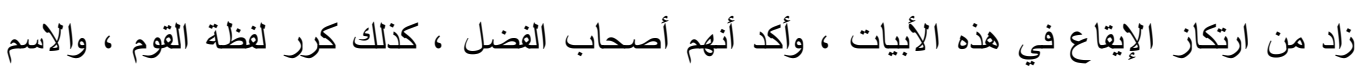

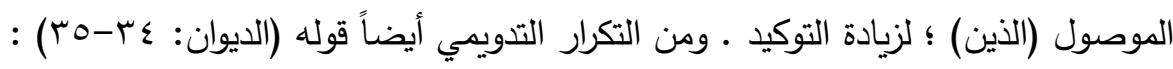




\begin{tabular}{|c|c|c|}
\hline 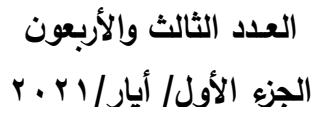 & & 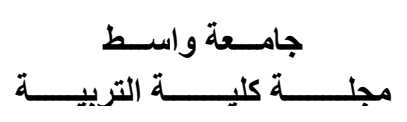 \\
\hline & وإنَّ صدورهم لكم بـراءٔ & ع ז- وإنَّ أباكمُ الأدنى أبوهم \\
\hline & وإنَّ نماءَهم لكمُ نمـــاءُ & هץ - وإنَّ سـعاتهم لكمُ سعاةٌ \\
\hline & وإنَّ وفاء هم لكمُ وفـاءُ & ج Y - وإنَّ سناء هم لكمُ سناءُ \\
\hline & على الأيام إنْ نفعَ البِلاءُ & V Y - وإنَّ بلاءَهم ما قد علمتم \\
\hline
\end{tabular}

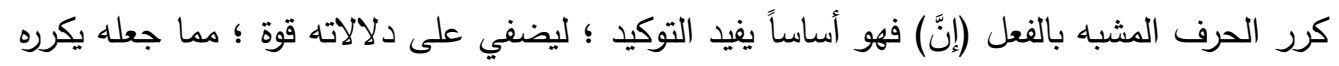

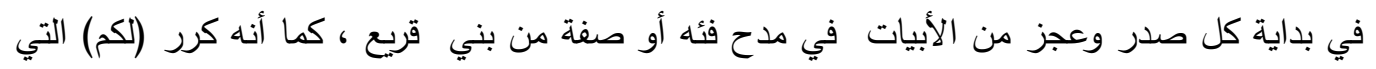

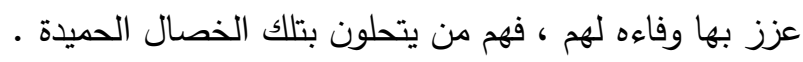

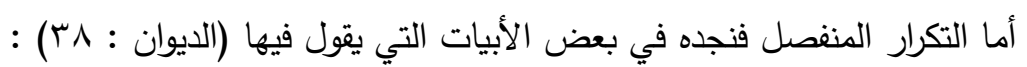

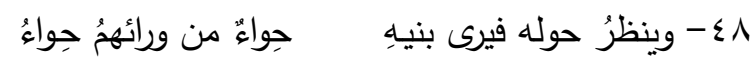

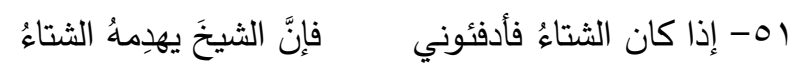

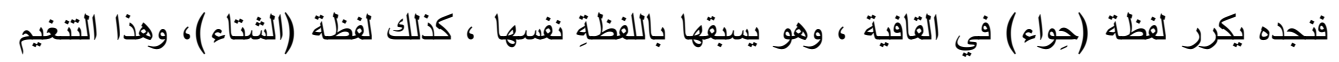
بالتكرار يجعل المتلقي أكثر تركيزاً على المفردات التي يحاول الثاعر التأكيد عليها ؛ لأنها تمثل مرتكزات

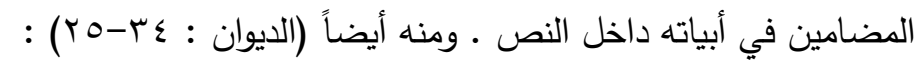

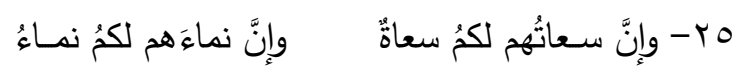

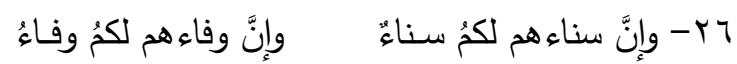

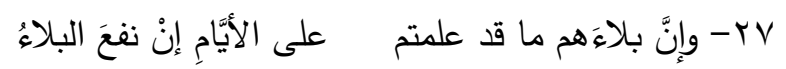

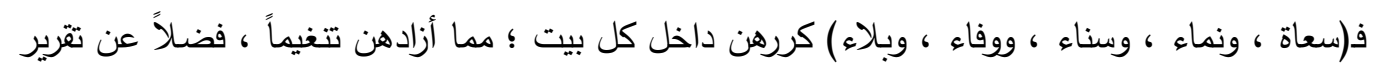

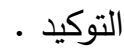

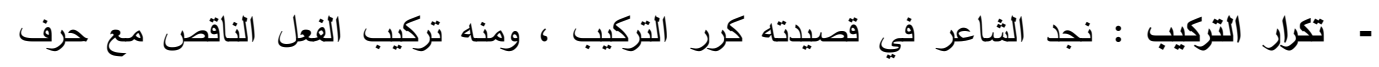

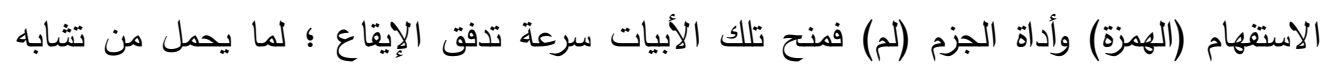

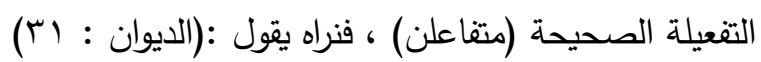

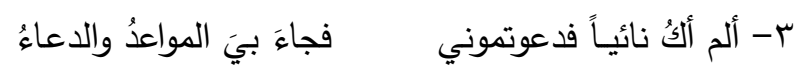

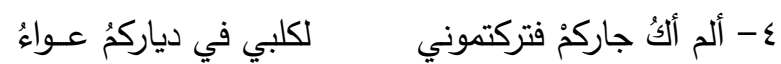

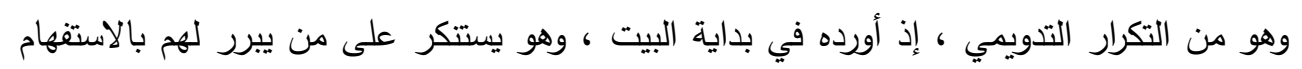
الإنكاري الذي حققه بالهمزة بحاليه حين دعوه ، وحين تركوه .

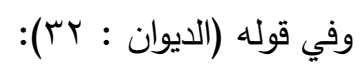

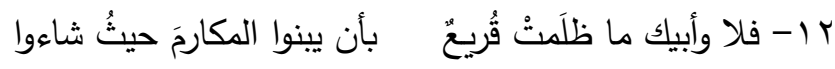


العدد الثالث والأربعون

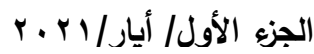

\section{جامسعة واستـط

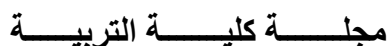

با ا - ولا وأبيك ما ظلمت قريعُ ولا برموا بذاك ولا أسـاءوا

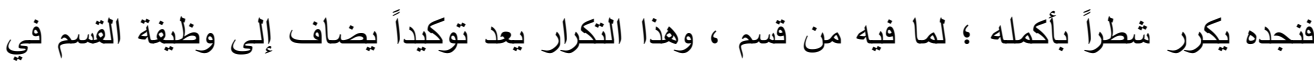
التوكيد .

يتبين أنَّ الثاعر في التوكيد يسعى في أغلبها إلى التوكيد التدويمي الذي يمثل تراتب التوكيد بالمحل

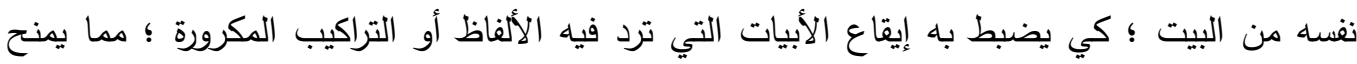

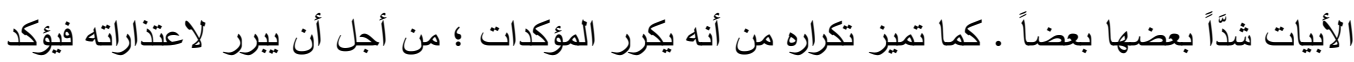

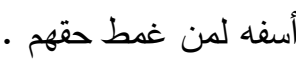
ץ- الجناس الاثتقاقي : وهو واحد من فروع الجناس الناقص الذي يضفي على النص جمالاً لفظياً ويلفت ذهن المتلقي بلفتاته النغية عن طريق إيراد الكلمة نفسها ، لكن بتغيير بعض والفئ مواقع حروفها فتميل

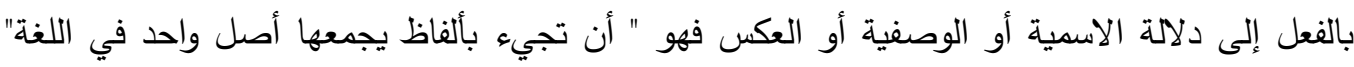

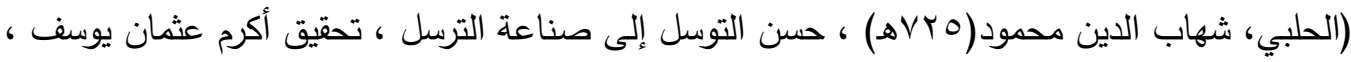

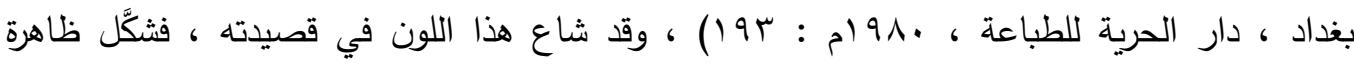

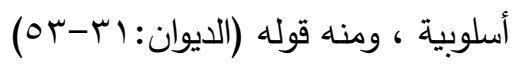

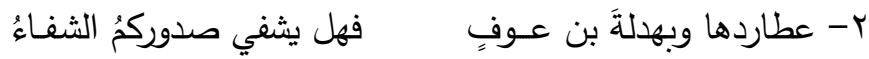

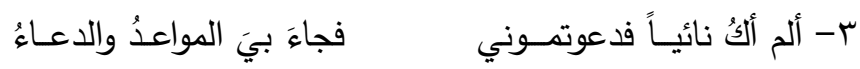

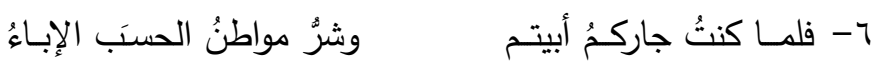

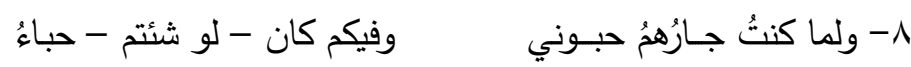

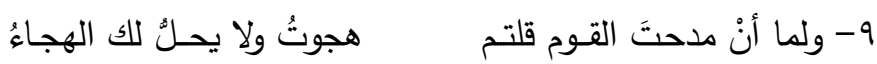

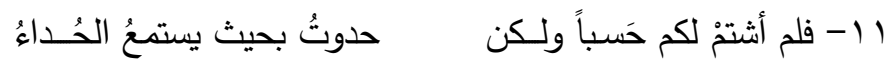

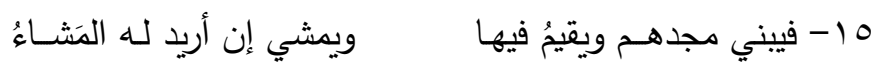

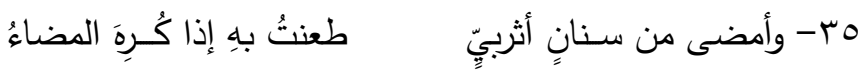

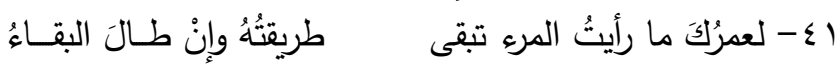

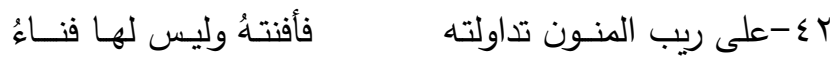

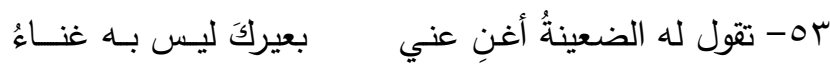

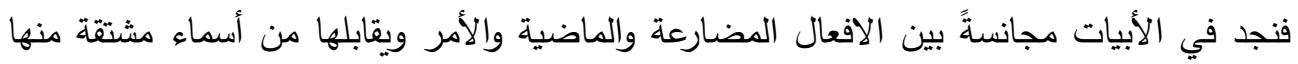

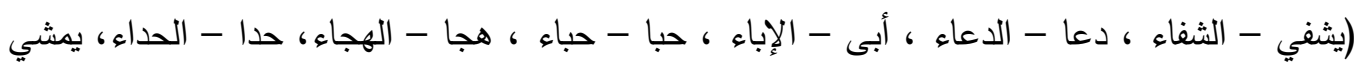




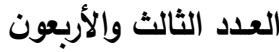

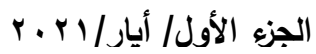

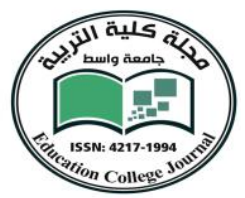

- المشاء ، تبقى - البقاء ، أمضى - المضاء ، أفنى - فناء ، أغنِ - غَناء) ، وهذه الالتفاتات في الجناسات الاشتقاقية تزيد النص تطريباً ، وقد أوردها الشاعر بكثرة بعدما بنى عليها قافيته .

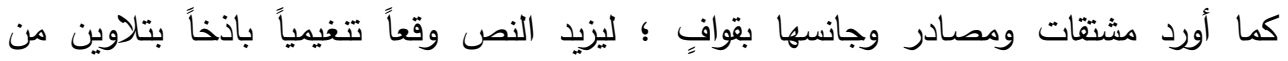

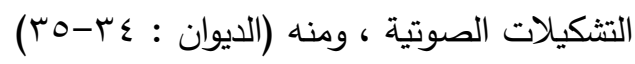

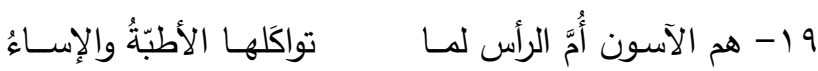

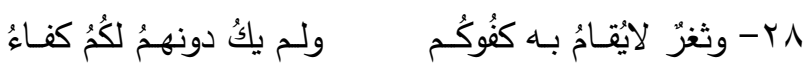

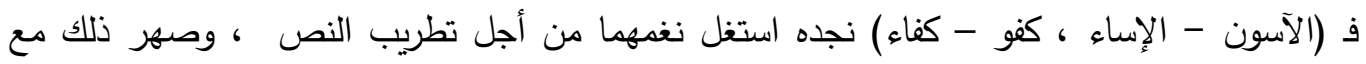

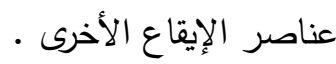

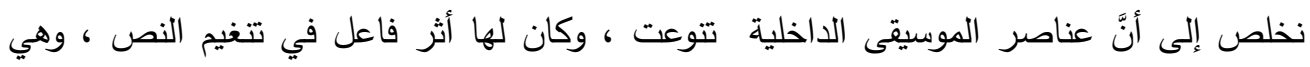

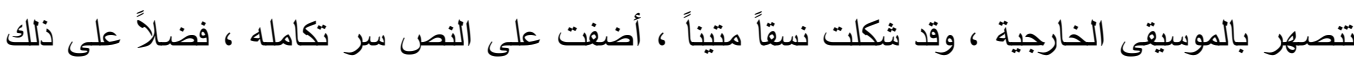
أغنته في الجانب التطريبي والتأثير النفسي عند المتلقي ، وبذلك شكلت مظهراً مائزاً من مظاهر أسلوبية

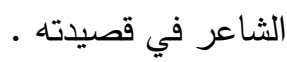

\section{المبحث الثاني}

المستوى التركيبي

النص الأدبي يتألف من ألفاظ وتراكيب تمنحه شعريته إذا ما استعملت كلغة خاصة للشعر تيمحه

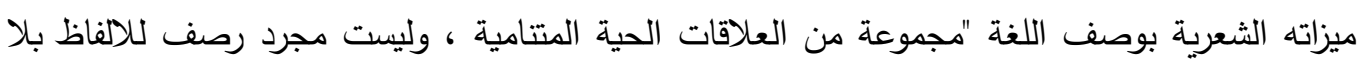

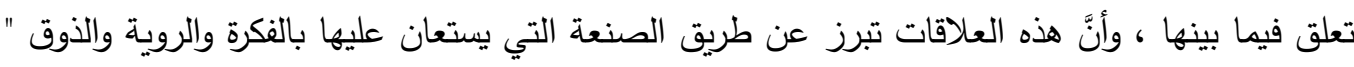

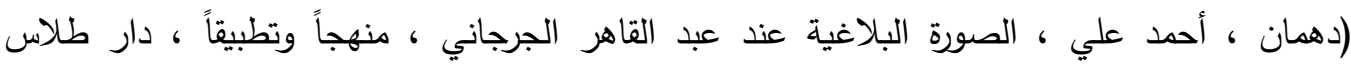

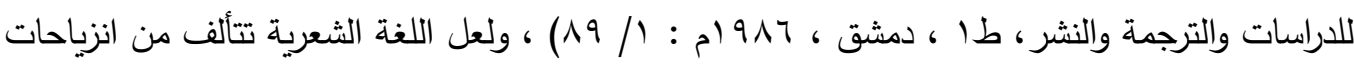

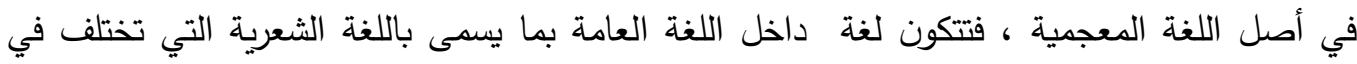

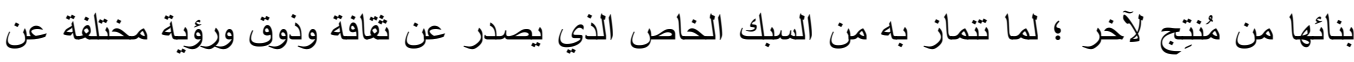

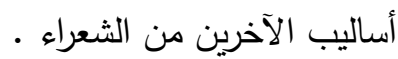

ولما كانت الاسلوبية تدرس أنساق النص بما فيها من خصائص الأسلوب ، ولاسيما التراكيب فالسمة

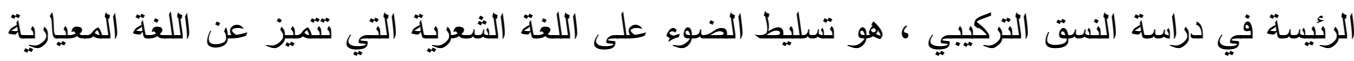

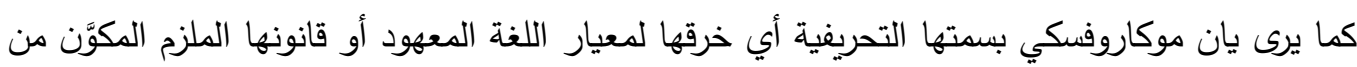
القواعد الصوتية والصرفية والنحوية بقصد التأثير بعد الإيصال (ينظر : الحربي ، فرحان بدري: الإسلوبية 
العدد الثالث والأربعون

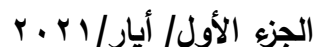

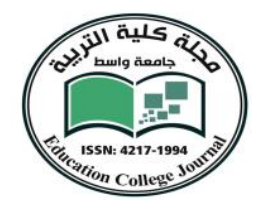

في النقد العربي الحديث دراسة في تحليل الخطاب ،المؤسسة العربية للدراسات والنشر والتوزيع بيروت ،

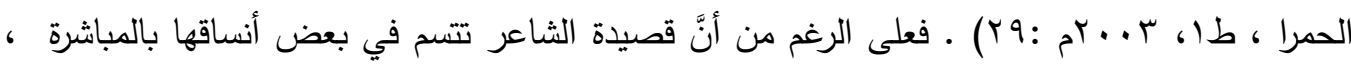
فإنَّ شعريتتها بدت واضحة في أغلب أنساق القصيدة الأخرى ، ومن ذلك : 1-أسلوب الاستفهام : إذ حقق الثاعر فيه جانباً من شعرية النص عن طريق ما حمله من معانٍ مجازية ، أومأ بها إلى دلالات متتوعة ، ومن تلك الأنساق الأسلوبية إيراد الاستفهام بالحرفين(هل والهمزة) للتعبير عن معنى الإنكار في (هل) بقوله (الديوان:ابس) : ا - ألا أبلغ بني عوف بن كعبٍ فهل قوم على خلقٍ سـواءُ ؟ فهو ينكر أن يكون هناك قوم جميع أفراده في الخلق متساوون .

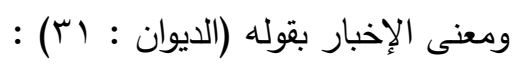

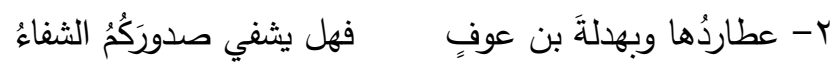
فقد استعمل الاستفهام هنا بالأداة (هل) للاخبار لا بمعنى الاستفهام ، أي (هل يشفيكم أن أبين لكم وأشفيكم من الخبر) (هامش الديوان : (ب)

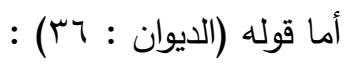
مب- وقد قالت أمامةُ هل تعزَّى فقلت أميم قد غلب العزائُ

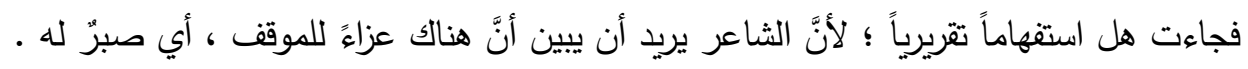
أما الهمزة ، فقد استعملها للعتب يقول (الديوان:اعب) :

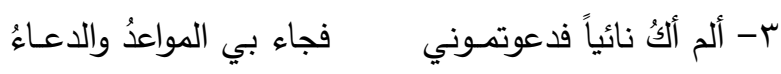
ع - ألم أكُ جاركم فتركتموني لكلبي في دياركمُ عــواءُ

فعلى الرغم من أنه يعتذر ، لكنه في الوقت نفسه يبرر لهم ماكان بينهم وبينه ، ليشعرهم أنه يتنازل عما لحقه منهم من تجشم المجيء في البيت الأول والحنين لهم في البيت الثاني • كما استعمل الهمزة للإخبار في قوله (الديوان : بr) :

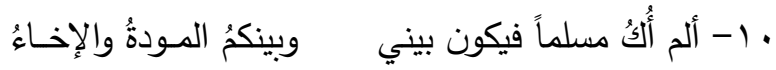

أي بيني وبينكُ حرمة الإسلام ، فلا ينبغي أن يساء إلي ، وواجب أن يكون بيننا المودة والإخاء . يتبين أنَّه استعمل نسقاً واضحاً في الاستفهام بحرفي الاستفهام دون غيرهما فأخرجهما إلى معاني الإنكار والإخبار والعتب .وهو ملمح أسلوبي واضت في نص الثاعر . 
العدد الثالث والأربعون

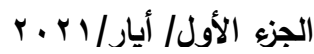

r- أسلوب الجمل المركبة بالثرط : من أنساق القصيدة الأسلوبية ، هو طغيان الجمل المركبة بأدوات الثرط ، وهو مظهر واضح لاى كل من قرأ القصيدة ؛ لييرر الثاعر به عمَّا يعتمله تجاه القوم الذين

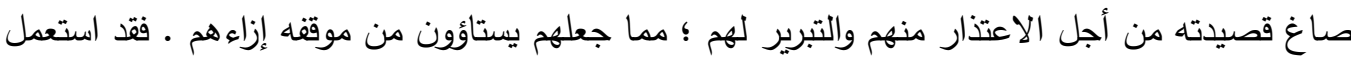
أدوات الثرط الزمانية ومنها (لما ، وإن ، و إذا)، إذ طغت في النص للتعبير عن وجهات نظر الثاعر

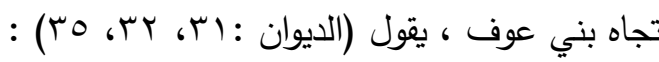

$$
\begin{aligned}
& \text { وشـر مواطن الحسب الإبـاءُ } \\
& \text { - فلما كنت جـاركمُ أبيتـم } \\
& \text { وفيكم كان - لو شئتم - حباءُ } \\
& \text { 1- ولما كنت جـارهُ حبـوني } \\
& \text { هجوتَّ ولا يحلّ لك الهجاءُ } \\
& \text { 9- ولما إنْ مدحت القـوم قلتم } \\
& \text { أتاني حيثُ أســمَعُهُ الدعـاءُ } \\
& \text { سب- ولَّْا أنْ دعوتُ أخي بغيضاً }
\end{aligned}
$$

فقد قرن لما بالزمن الماضي ، وهو يعتب بها عليهم ؛ ليكثف أنه على حقٍ في وجوهٍ كثيرة منها إباؤهم عليه على الرغم من أنه جارهم ، بينما ابن شماس من بني قريع حباه ، ولم يعطوه على الرغم من بن قدرتهم على العطاء ، والبيت التاسع أنه حين مدح ابن شماس عدُّه هجاء لهم ؛ كونه فضله على الزبرقان بن بدر من بني عوف في غير موضع •(ينظر : أبو الفرج الأصبهاني : علي بن الحسين ، دار

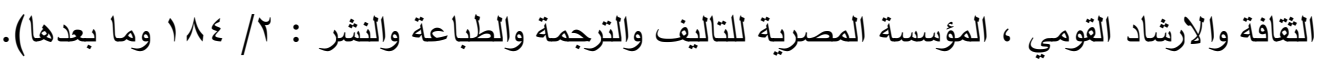
والذي يغري بالقول أنَّ الثاعر استعمل لمَّا الثرطية ؛ لما فيها من التقريرية التي هو بحاجتها في

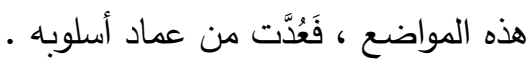

أما إنْ الثرطية ، فقد استعملها الحطيئة ، وهي ظرف لما يستقبل من الزمان ، فقد جعلها في حشو الأبيات ،ولم يجعلها تتصدر الكلام ؛ ليخفف من وطأة اللوم تجاههم ، يقول (الديوان :rس وما بعدها)

$$
\begin{aligned}
& \text { 10 - فيبني مجدهـم ويُعِيُُ فيها }
\end{aligned}
$$

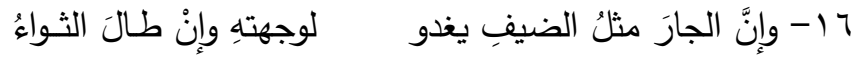

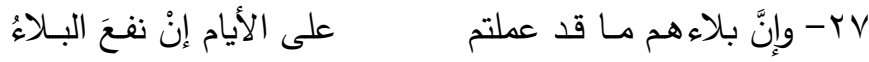

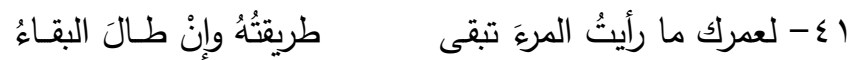

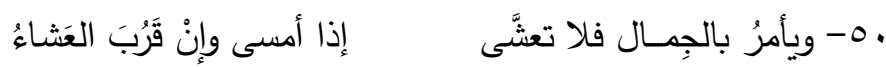

فقد استعمل (إنْ) لندرة تحقق الفعل معها ؛ لذلك أفاد منها تلك الدلالة ، فأفعال الشرط نادرة الوقوع معها ، وهي: (أريد ، طال ، نفعَ ، طال، قربَ) وجوابها الذي يندر تحققه ؛ لندرة تحقق الأفعال ، وهي : (يبني ويقيم ويمشي كيغدو ، بلاءهم ، تبقى ، لاتعشَّى) ، فقد جعلها في حشو الأبيات ؛ كونه غير متفائلٍ 


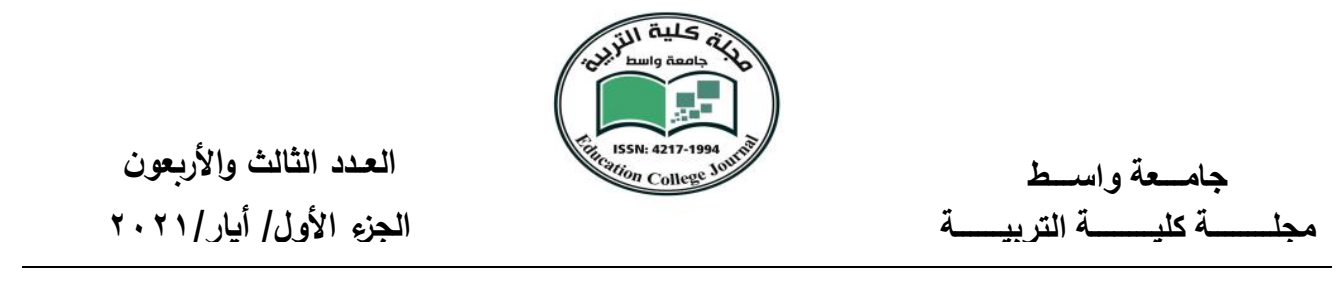

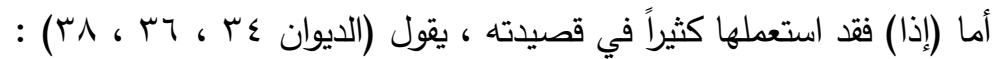

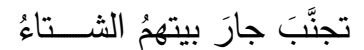

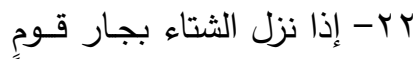

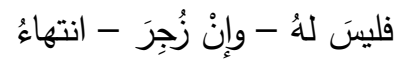

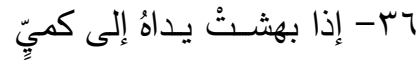

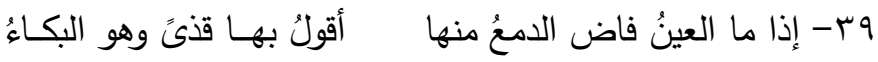

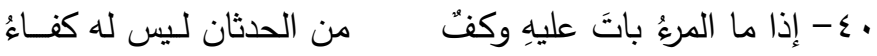

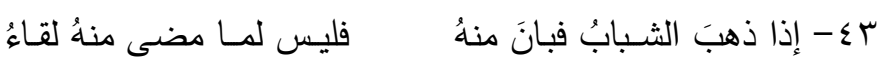

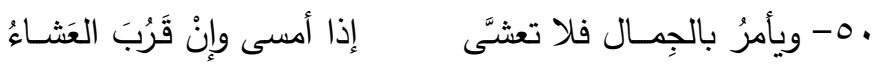

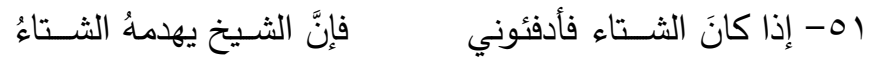

نجد (إذا) تتصدر معظم الأبيات ؛ لما فيها من تحقق الجواب ؛ كون (إذا) تستعمل مع التحقق إنق

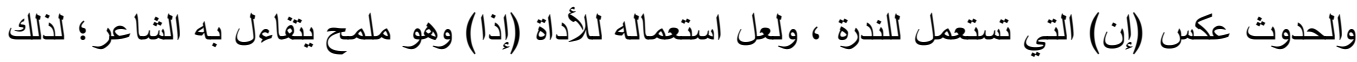

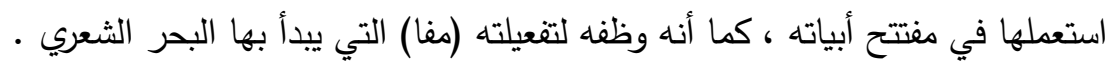

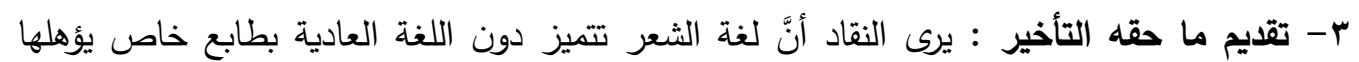

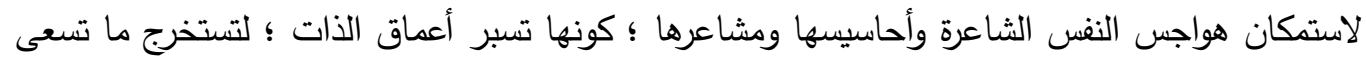

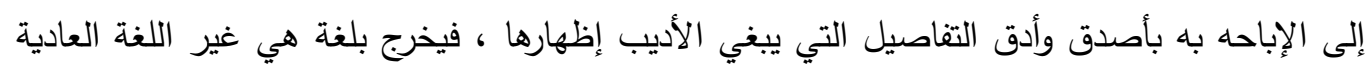

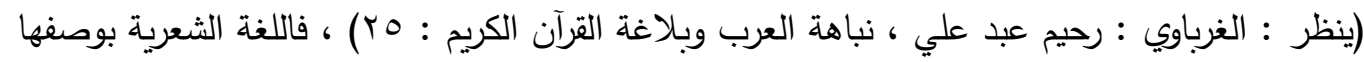

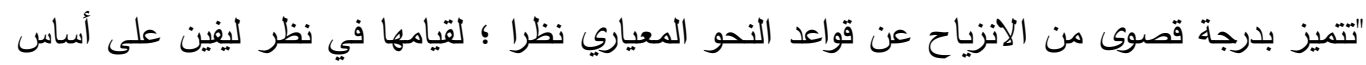

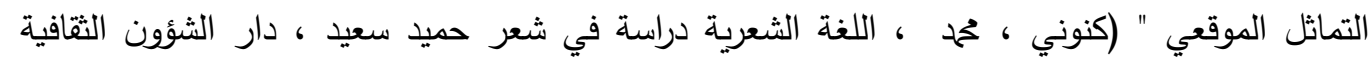

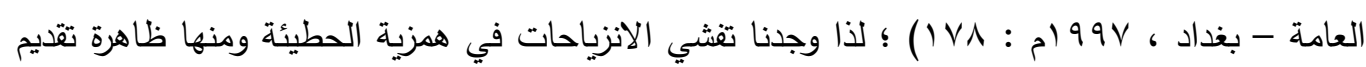

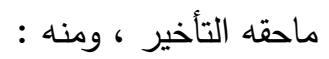

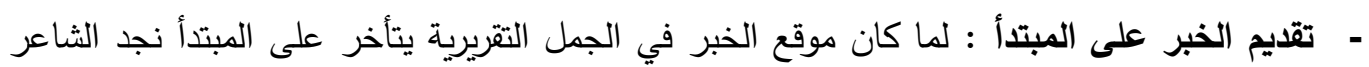

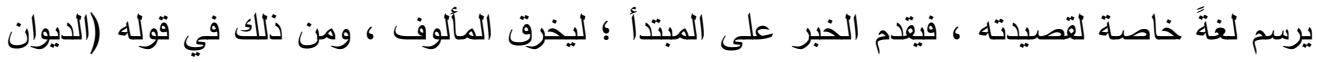

$$
\text { : }
$$

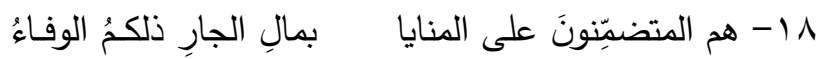

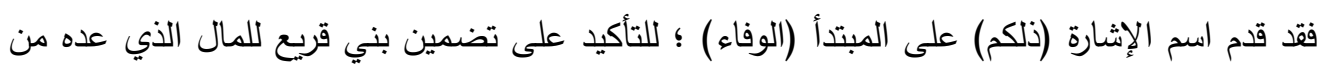
الوفاء ، فأشار لفعلهم بالخبر ، ثم وسم ذلك الفعل بأنه الوفاء .

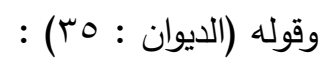

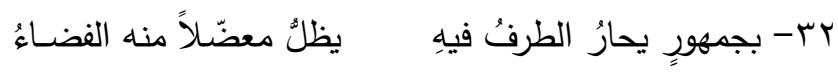


العدد الثالث والأربعون

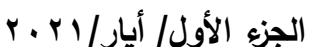

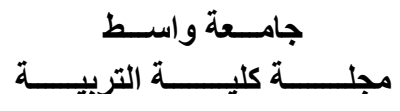

فلفظ (معضلاًا) خبر مقدَّم على اسم ظلَّ (الفضاء) ؛ وذلك للاهتمام بما هو واجب النظر فيه .

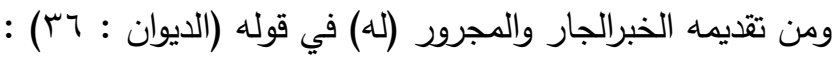

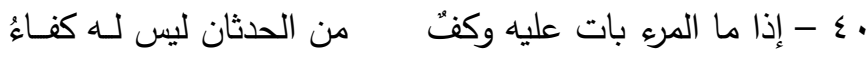

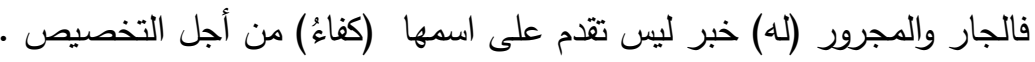
ومثله قوله (الديوان : ب بس) :

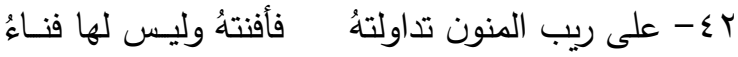

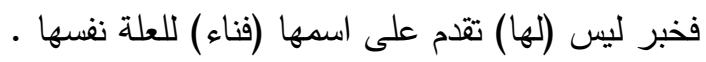

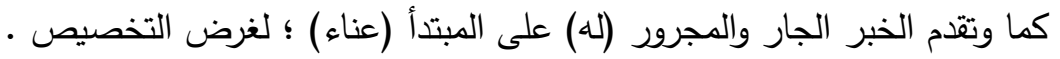
ومثله في قوله (الديوان :

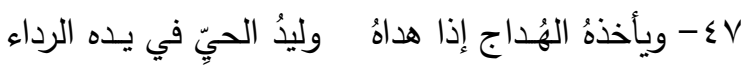
إذ نراه قدم الخبر الجار والدجرور (في يده) على المبتدأ الرداء ـ الداه - ت تقديم المفعول به ، ومنه (الديوان : عب) :

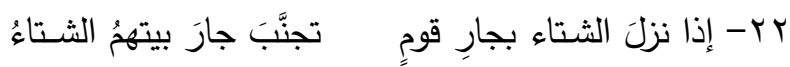
فقد قدم المفعول به (جارَ) على الفاعل ( الثتاء ) للاهتمام بالمتقدم ؛ وذلك لبيان كرم الممدوح الذي لـاء

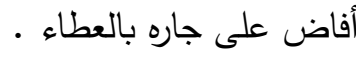

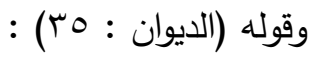

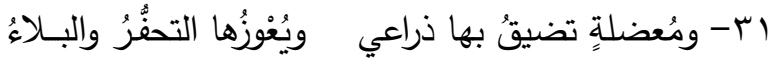

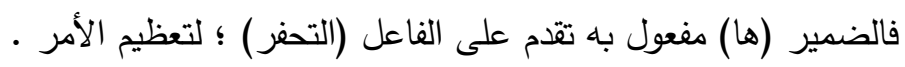
وقوله (الديوان : مبr) :

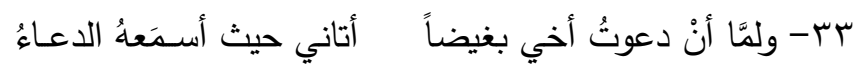

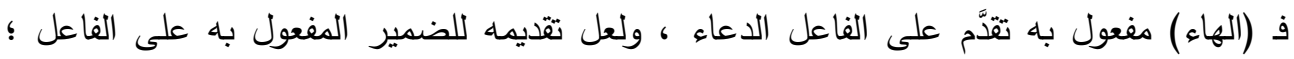

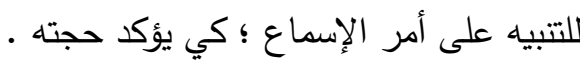

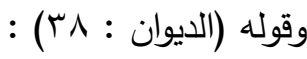

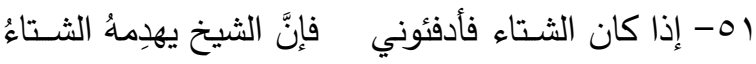
فالمفعول به الضمير (الهاء) المتصل بالفعل يهام المتقدم على الفاعل الثتاء.من أجل التوكيد .

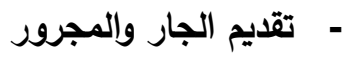
ومن تقديم الجار والدجرور على الخبر في قوله (الديوان : آب): 
العدد الثالث والأربعون

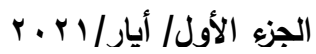

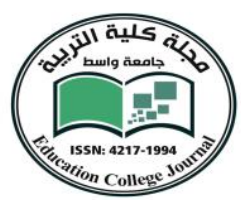

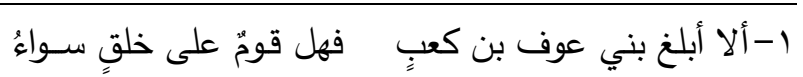

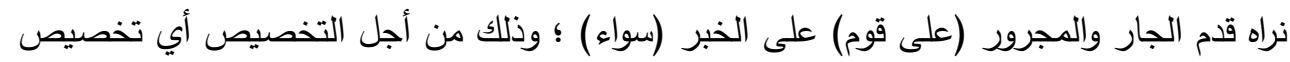

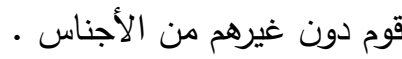

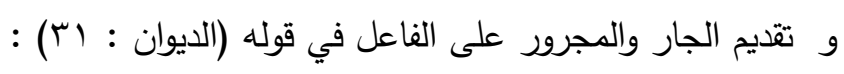

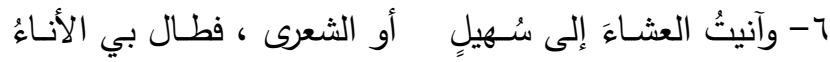

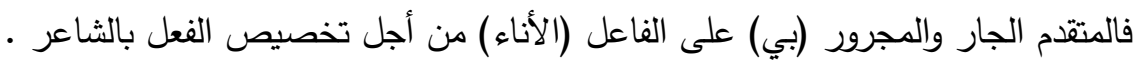
ومثله (الديوان :rr) :

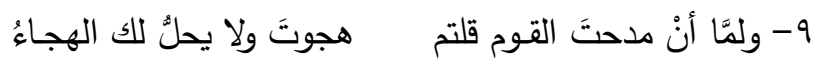

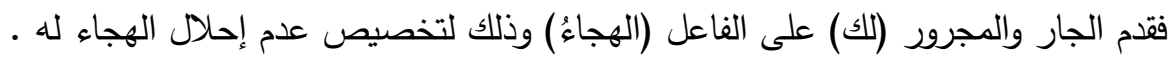

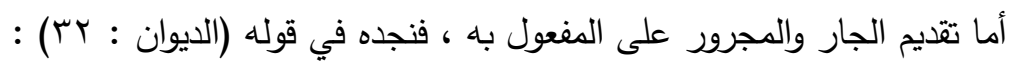

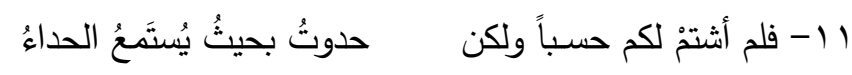

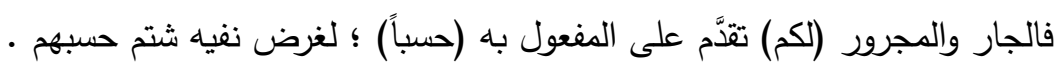

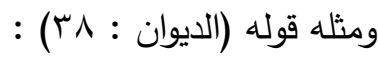

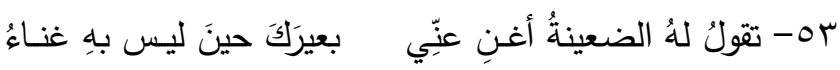

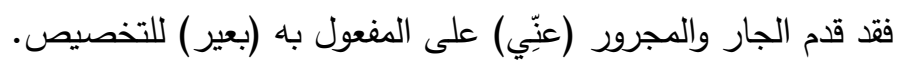

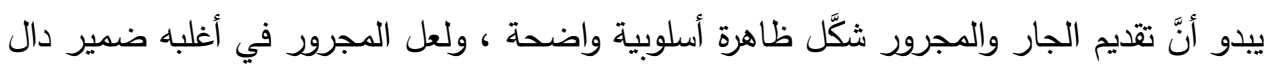

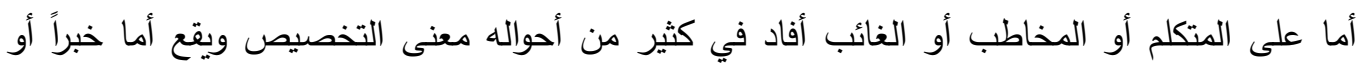

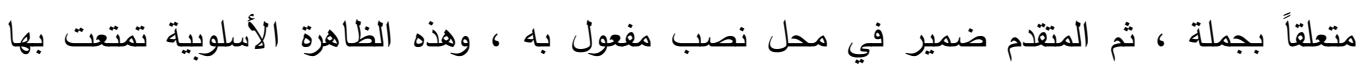

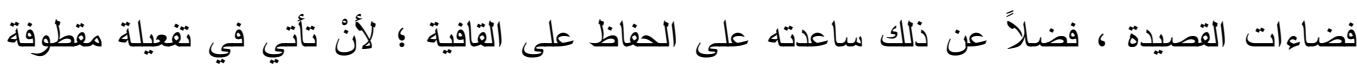
(فعولن) צ- الضمائر :

تمثل الضمائر الجهة الناطقة في النص التي من خلالها ينفتح المعنى ويتسع ، إذ شكَّل ذلك لائ

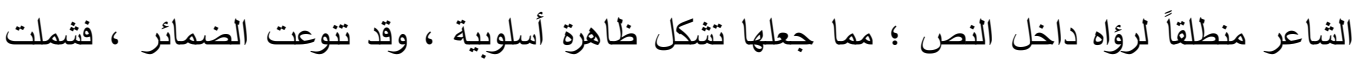

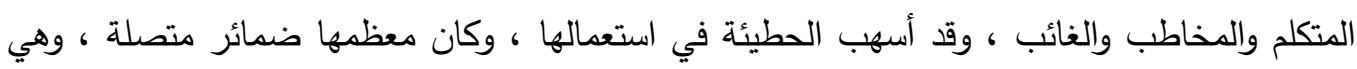
حسب الجدول : 


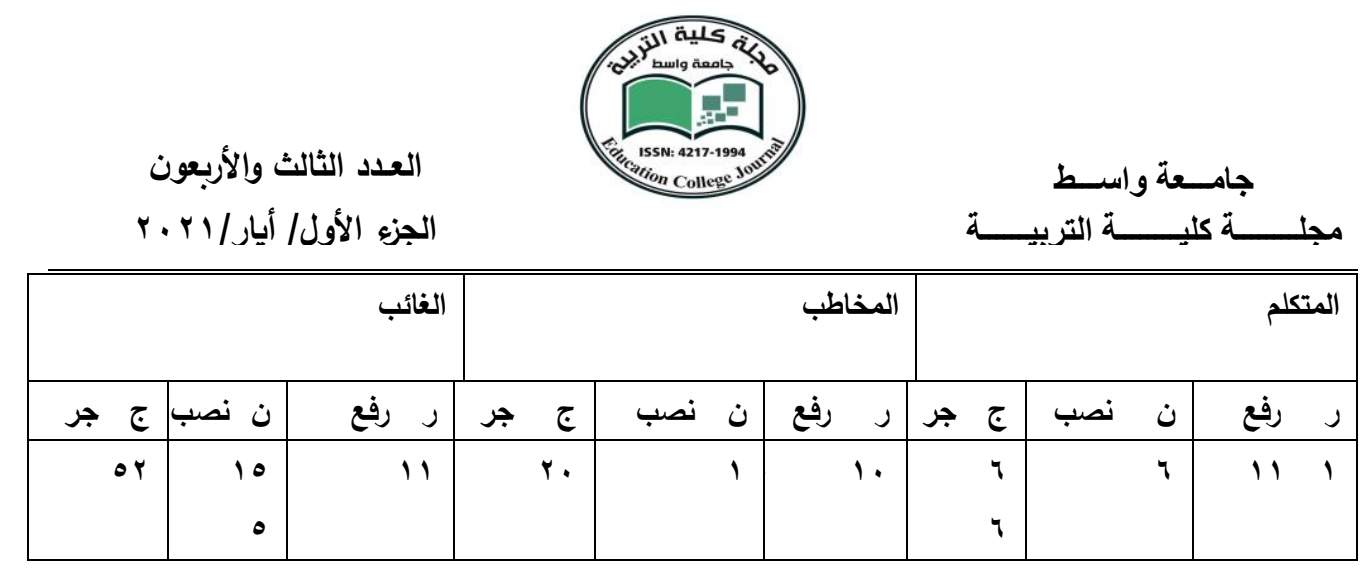

ويبدو أنَّ مخاطبته للغائب الذي يمثل صاحب كرم وفضل على الثاعر ، قد أورده ضمير رفع

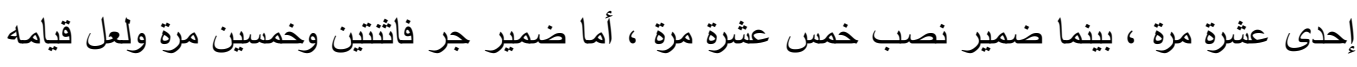

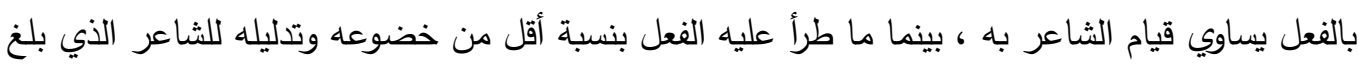

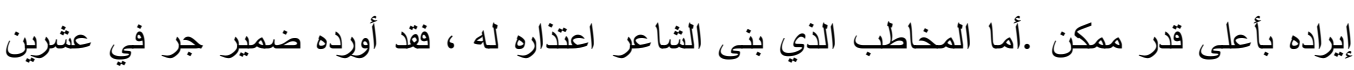

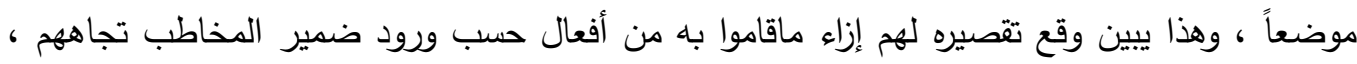

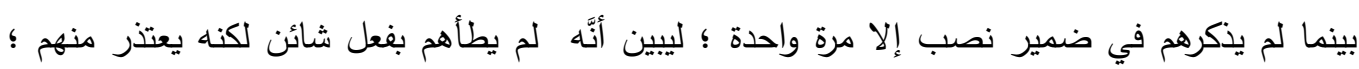

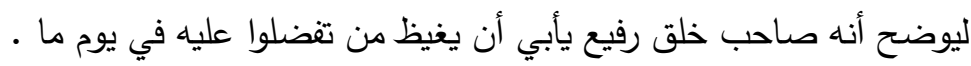

المبحث الثالث

المستوى الدلالي

لما كانت الأسلوبية تعزف عن إرسال الأحكام المعيارية والتقييمية بالمدح أو التهجين (ينظر : الإلي

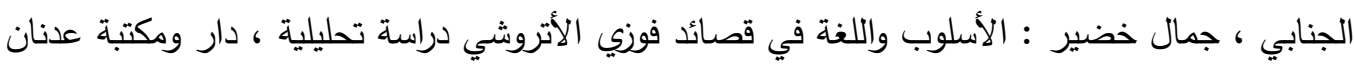

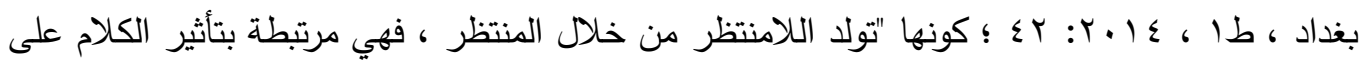

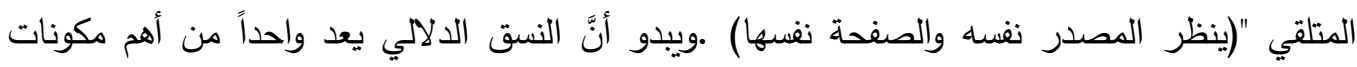

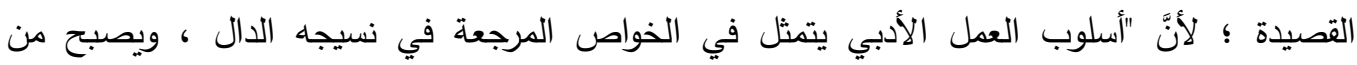

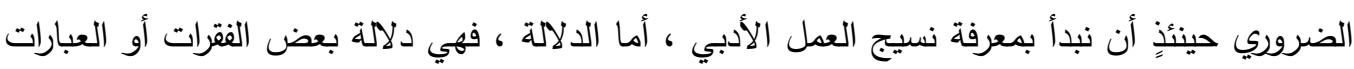

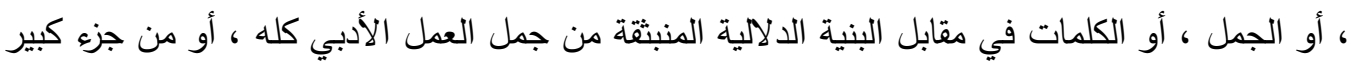

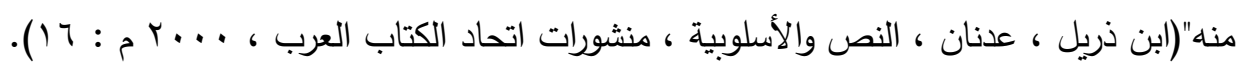

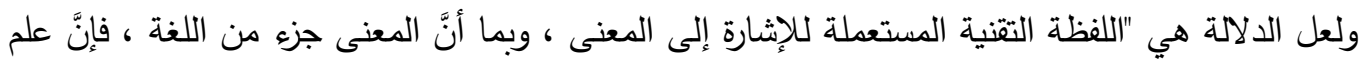

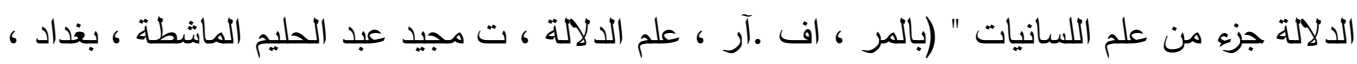

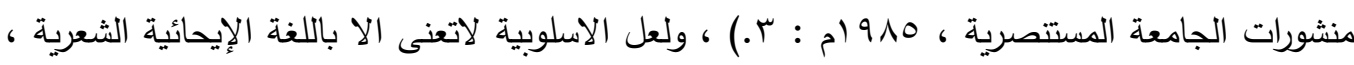




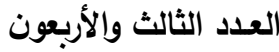

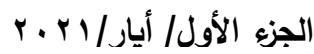

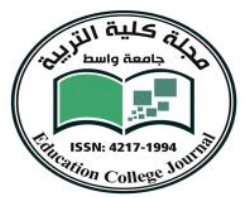

فمن خلال المعنى المعجمي اللغوي يمكن الوصول إلى المعاني الايحائية التي تمثل النسق الأسلوبي الدلالي عن طريق أساليب اللغة البنائية .

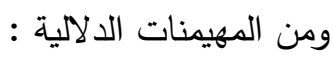

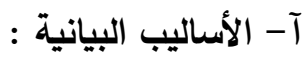

وهي أساليب فنية إيضاحية تورد المعاني بطرق مختلفة ؛ ما يمنح النص قدراته الإبلاغية والبلاغية

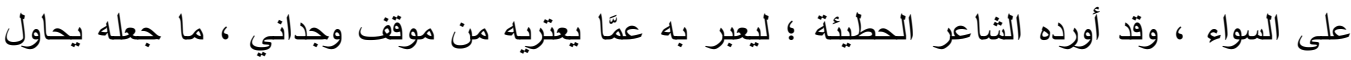

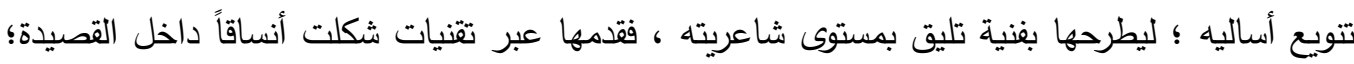

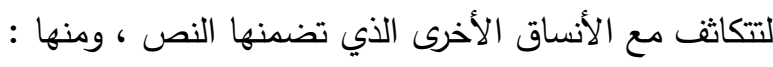

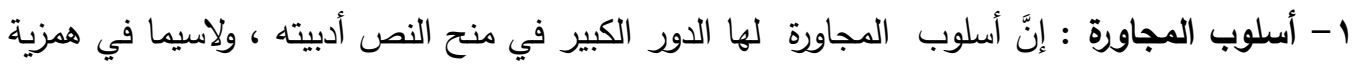

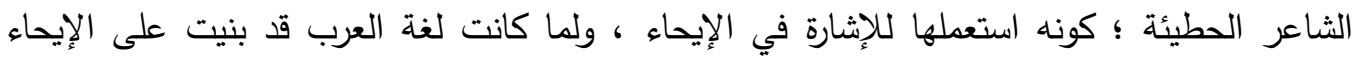

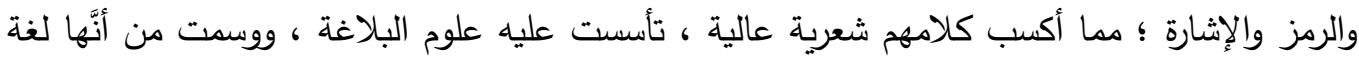

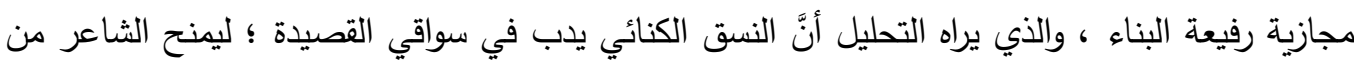

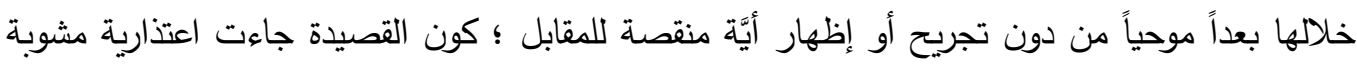

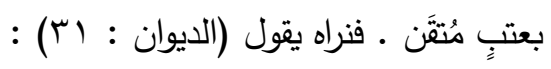

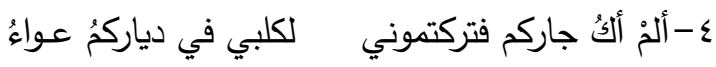

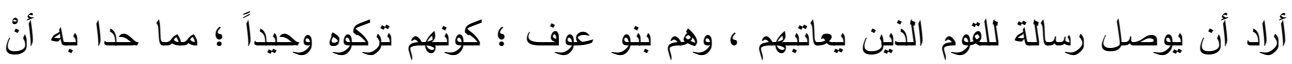

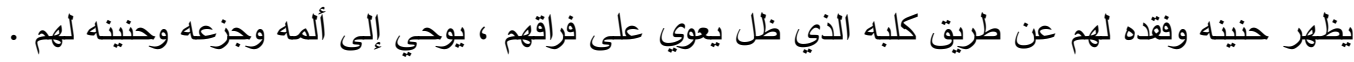

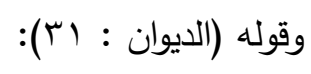

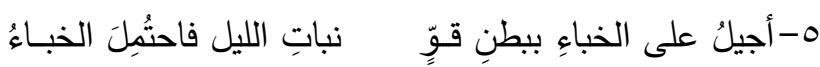

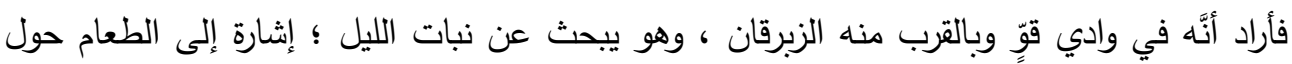

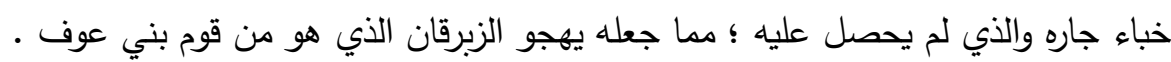

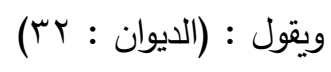

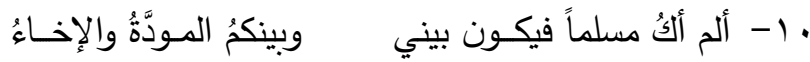
نراه يقرر في هذا البيت أنَّهَ مسلم ؛ إثارة إلى الحرمة التي يحملها الإسلام في إيواء الجار واحترامه

$$
\text { ويقول والديول الواجبات إليه . }
$$

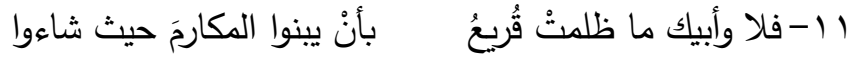




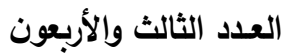

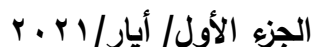

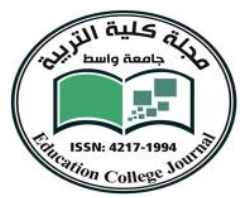

فبناء قُريع للمكارم حيث شاءوا ؛ يومئ إلى سخائهم وكرمهر ، وهي الخصلة المفضلة لاى العرب وهم يتسابقون على إعلائها ، ويتفنتون بجلبها لهم إعلاءً لمكانتهم بين العرب ، وهذا الإطراء يمثل عتب إتباء

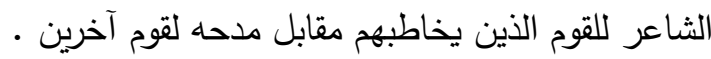

$$
\text { ويقول (الديوان : بr): }
$$

ـ ا - بعثرة جارهم أنْ ينعشوها فيغبرُ حوله نعمٌ وشـاء

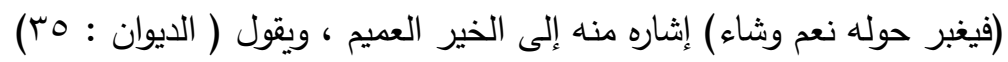

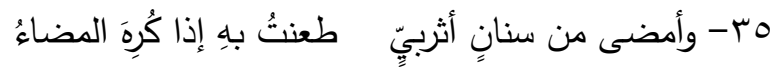

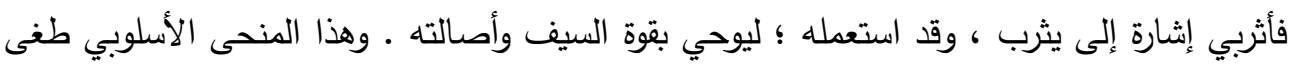

على فضاء القصيدة .

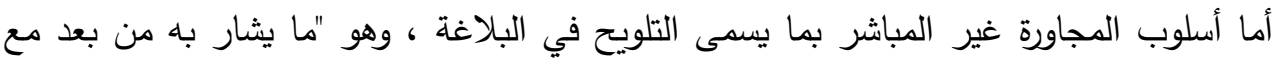

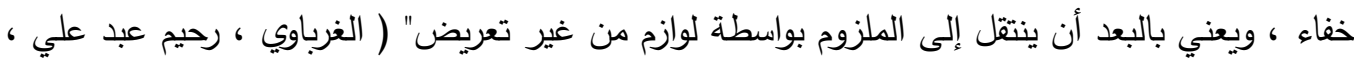

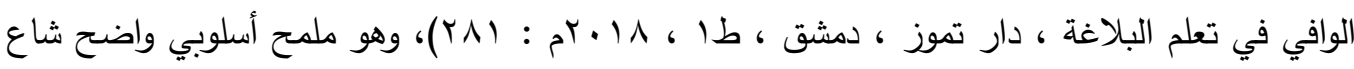

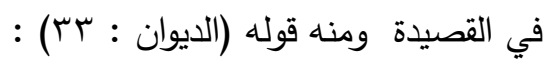

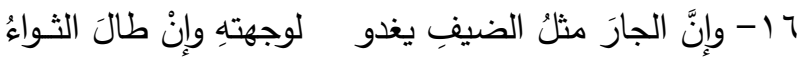

فهو يوسم نفسه بأنه مثل الضيف بحاجة إلى اهتمام ؛ كون مكانة الجار عند العرب مميزة ولاسيما

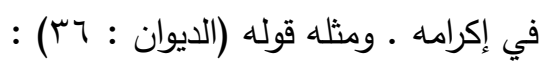

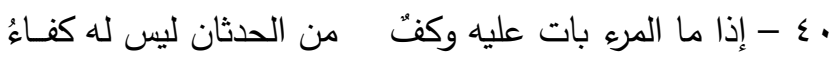

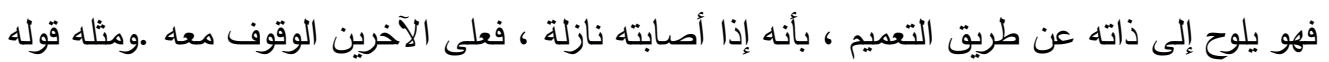

: (الديوان :4r)

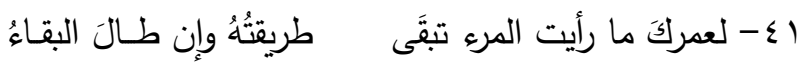

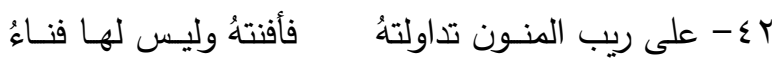

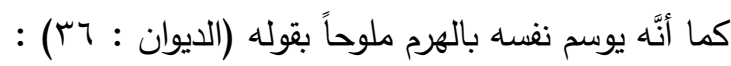

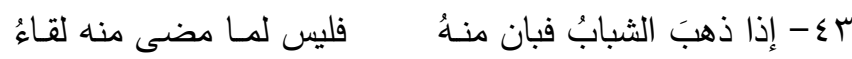

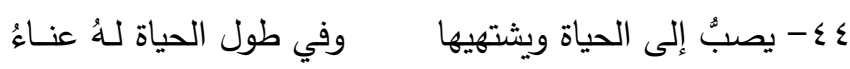

ولعل هذا الأسلوب يمثل صورة واضحة لوحدة النص الموضوعية ، كما أنَّهَ ملمح متداول لثعراء

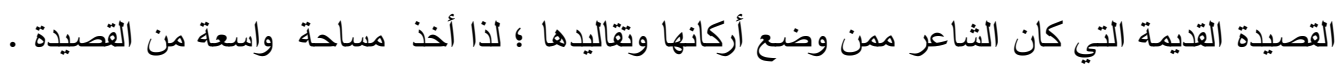


العدد الثالث والأربعون

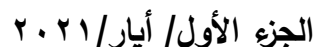

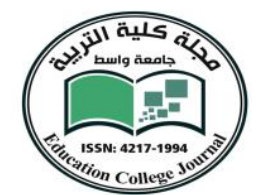

(1) 
العدد الثالث والأربعون

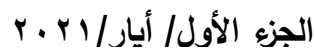

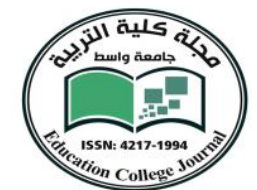

فالثاعر يعظم الثفاء الذي فاض من القلوب حتى ملأ الصدور مستعملاً لفظة الصدور التي يقصد

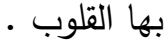

$$
\begin{aligned}
& \text { وقوله (الديوان : بr) : }
\end{aligned}
$$

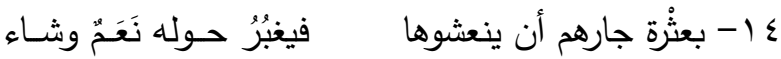

فالنعم والثاء لاتغبر وإنما ظلالها ؛ إذ يبدو للرائي عن بعد مغبراً محاولاً أن يطغي دلالة كثرة النعم

والثاء بينما هو لم يحصل إلا على ماتثيره تلك النعم من غبار •

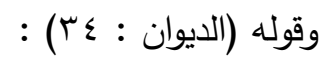

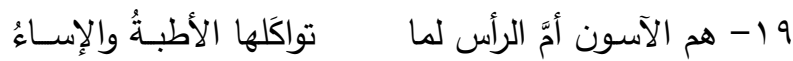

فأم الرأس أعلى قمة في الجسد أشار بها إلى الجسد كله .

$$
\text { وقوله (الديوان :0ب) : }
$$

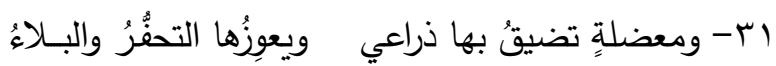

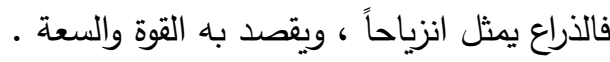

$$
\text { وقوله (الديوان :0ب) : }
$$

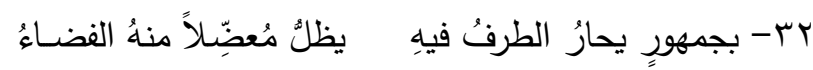

فالثاعر يذكر الطرف ، كونه جزءاً من العين واستعماله للطرف بوصفه موئل الحركة والاتجاه . ولعل الانزياح العلائقي حمل طابعاً تداولياً باستعمال الثاعر ماهو محسوس ، وجميع ما ورد يمثل

$$
\begin{aligned}
& \text { جزاء من الجسد • وهو ما شاع في أسلوب الأقدمين . } \\
& \text { ع - أسلوب الاستبدال : من : }
\end{aligned}
$$

وهو واحد من الأساليب البيانية التي تمتَّعت به همزية الحطيئة ، ولون من ألوان شعرية النص التي تبوح بالمعنى الإشاري ، استعملها الثاعر للتعبير عن هواجسه وانفعالاته ، ومنها قوله (الديوان : اسب) :

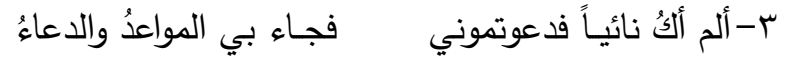
فالمواعد لاتجيء وإنما يجيء صاحبها ؛ ليقترح ويعزز معنى بيته بالفرادة قصد التأثير بأسلوب

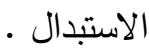

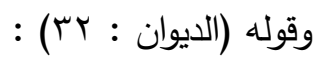

r ا -فلا وأبيك ما ظلمت قربع بأن يبنوا المكارم حيث شاءوا : إنَّ استعماله استبدالا لمفرداته ؛ ليقرب صورة المكارم التي تثيَّّ كما البيوت ، وهي بحاجة إلى جهد 


$$
\begin{aligned}
& \text { العدد الثالث والأربعون }
\end{aligned}
$$

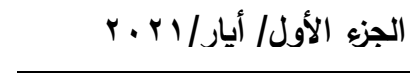

$$
\begin{aligned}
& \text { ind } \\
& \text { وقوله (الديوان : بr) : } \\
& 10 \text { - فيبني مجدهم ويقيم فيها ويمشي إنْ أريد لهُ المشـاءُ } \\
& \text { إذ أنَّ المجد لائينى والذي يُبنى هي الدار وغيرها من المحسوسات . } \\
& \text { وفي قوله (الديوان : سب) : } \\
& \text { IV }
\end{aligned}
$$

ولفظة حبل هي ليست في موضعها الحقيقي ، فجاء بها ؛ ليبين الارتباط بينه وبين القوم ، مشبهاً

وسيلته بالحبل الموصول بين الطرفين •

$$
\text { وقوله (الديوان : ع بان) : }
$$

r ب- إذا نزلَ الثـتاءُ بدارِ قومٍ نراه يعقد صورة للشتاء بأسلوب الاستبدال برجل ينزل ؛ لتقربب الصورة ؛ وإضفاء جانب من المبالغة

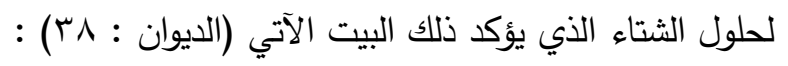

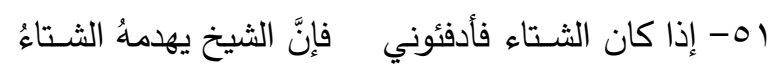
فنراه يؤكد ضعفه وخور قواه ومبالغته في الثتاء ، فجاء به في سياق استبدل فيه لفظة بدل أخرى ، فلفظة الشتاء الواردة لاتهدم إنما المعاول هي ما تهدم • فالثاعر استعمل أسلوب الاستبدال على طريقة البلاغيين بما يطلق عليه بالاستعارة المكنية بحدود

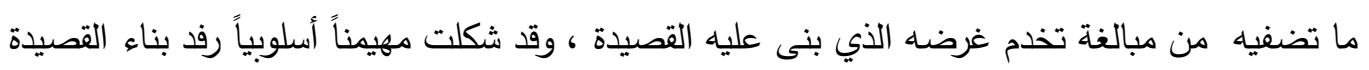
•الفني

$$
\text { ب - التحول والثبات : }
$$

يبدو أنَّ همزية الحطيئة تتحرك دلالياً في اتجاهين : الأول : هو اتجاه التحول الذي حقتته الجمل الفعلية ، والآخر الثابت وحققته لله الجمل الاسمية ، وكلا الاتجاهين شاع في القصيدة بما ينسجم ودلالات السياقات التي عبَّر بها الثاعر عن مضامين قصيدته ، ولما كان الحطيئة يبغي الاعتذار من بني عوف والذي بنى قصيدته على هذا الأساس راح يظهر تحسره وألمه تجاه هؤلاء القوم بالاتجاه الأول ؛ ليباري ما ألمّ به من انقطاعهم عنه ، رافضاً التكيف مع هذا الحال ، فراح يجول من أجل كسب ودّ القوم إليه مقارناً تعاملهم معهه بالجفاء ، بينما يقرن تعامل بني قريع الذي عاش معهم بطمأنينة واستقرار ؛ لما أغدقوا

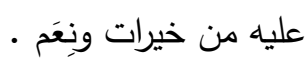




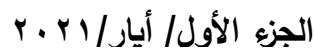

العدد الثالث والأربعون

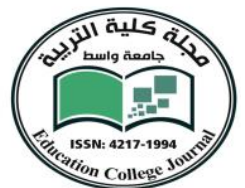

ومن المتحول في النص قوله (الديوان: اب وما بعدها) : 0- أجيل على الخباء ببطنِ قوٍّ نباتُ الليل فاحتُمِلَ الخباءُ 7- وآنيتُ العشـاءُ إلى سـهيلٍ أو الثعرى فطالَ بي الأناءُ

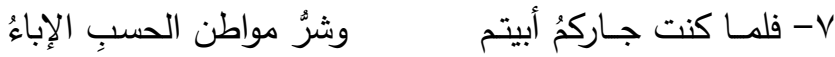
9- ولما أنْ مدحت القوم قلتم هجوت ولا يحلُ لك الهجاءُ

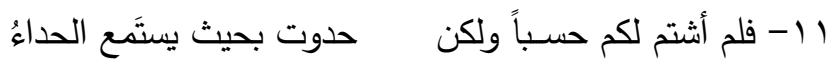

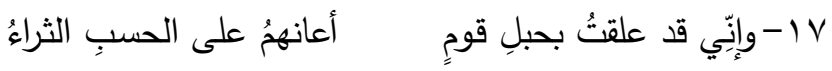

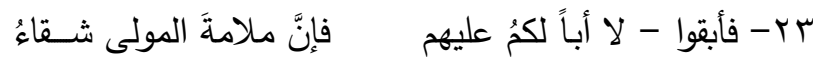

فنراه حين يخاطب القوم الذي يعتب عليهم وفي الوقت نفسه يقدم اعتذاره يستعمل الجمل الفعلية وهي (أجيل ، آنيت ، أبيتم ،مدحت - هجوت ، حدوت ، أعان ، أبقوا) وجميعها تمثل حركة وتجدد في الحدث ، لما للقوم الذين يخاطبهم من أفعال صدرت ضده ، وتغير مواقفهم تجاهه . ونراه حين يفخر بنفسه يستعمل المتحول أيضاً عن طريق الأفعال ،ومنه في قوله (الديوان : هب وما بعدها):

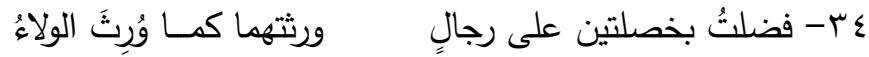

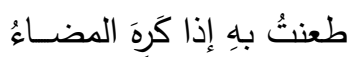
هب-وأمضى مـن سـنانٍ أثربيّ فليس للهُ وإنْ زُجـرَ انتهاءُ إنهاء

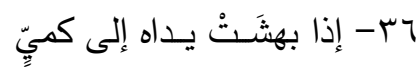
فقلتُ أميم قد غُلب العزاءُ ^ץ- وقد قالت أمامــةُ هل تعزَّى فأفنته وليس لـه فنـــاءُ r فليس لمـا مضىى منه لقـاءُ بـ - إذا ذهبَ الثـبابُ فبان منهُ وفي طول الحياة لـهُ عنـاءُ ع - يصبُّ إلى الحياة ويشتهيها وليدُ الحيّ في يـده الـرداء 乏V حواءٌ من ورائهُ حـواءُ ^ - وينظر حولــهـ فيرى بنيهِ لأمسوا معطشين وهم رواءُ

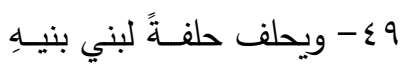
إذا أمسى وإنْ قربَ العشاءُ

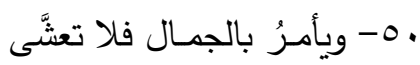
بعيرك حين ليس بهِ غذ،اءُ

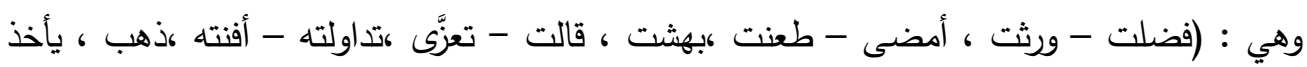

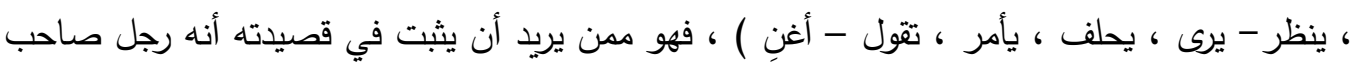




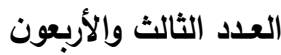

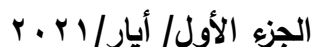

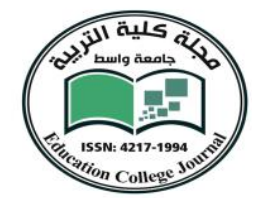

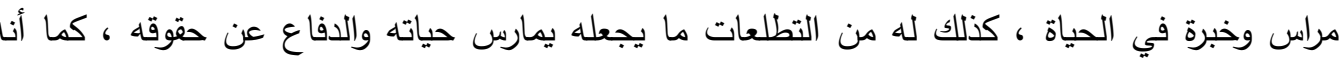
الرجل الثجاع في المواقف ، و أنه حين بلغ الثيخوخة صار يحتاج العون والمساعدة ، فذهبت فئ قوته وبداء

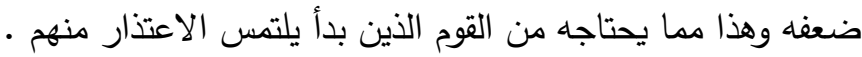

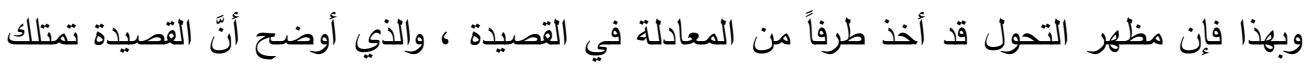

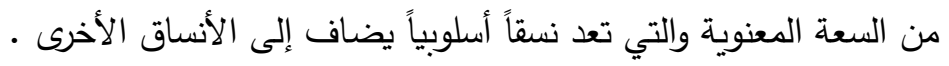

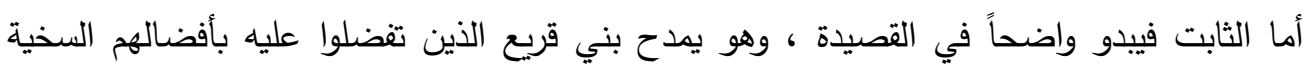

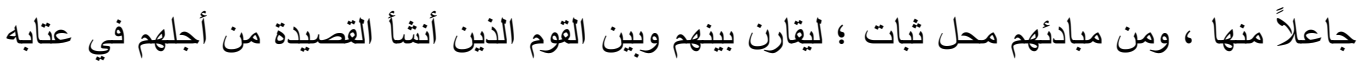

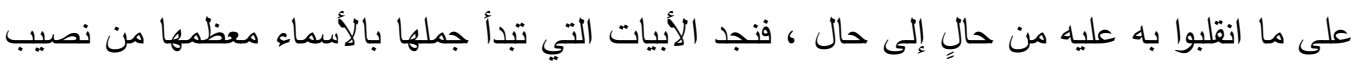

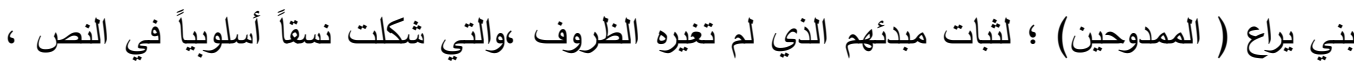

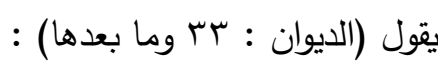

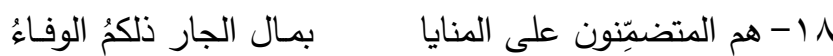

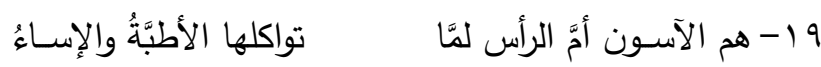

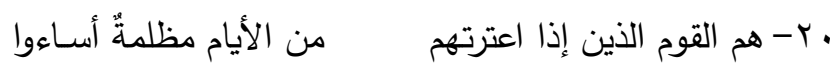

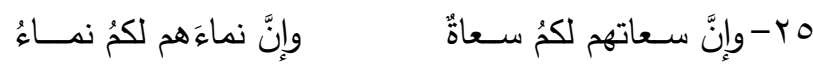

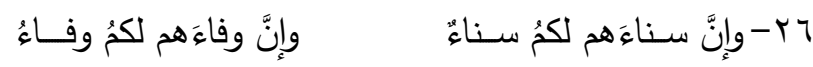

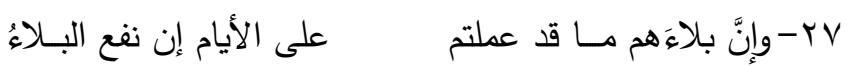

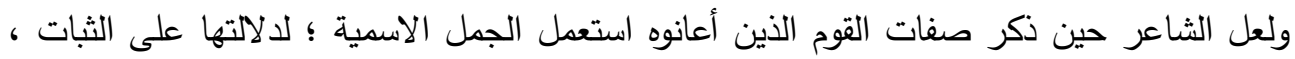

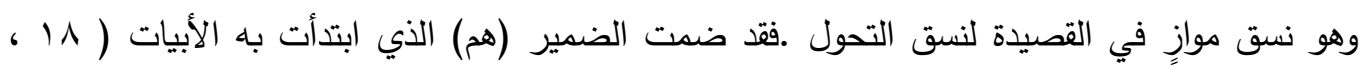

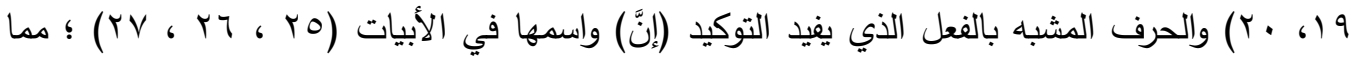
يدلل على شدة ثبات السمات الطيبة لديهم . وبذلك حقق الثاعر نسقين مضمرين في النص دلَّ دلالة فارقة أنَّ الثاعر حين يعتب له دليله

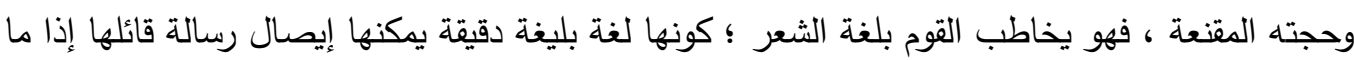

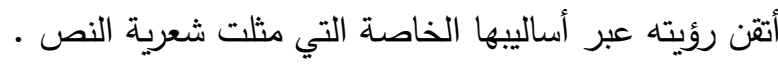


العدد الثالث والأربعون

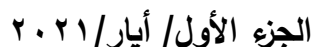
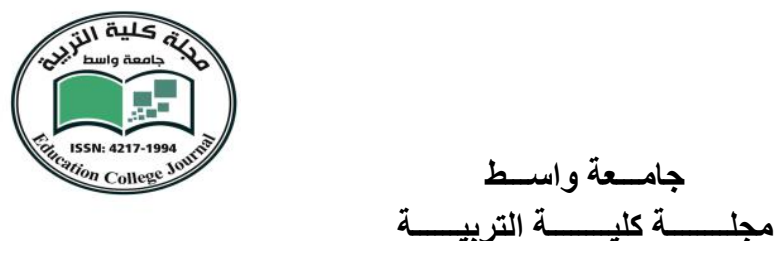

ج- الموازنة بالأضداد :

الأضداد من المهيمنات الأسلوبية استعملها العرب ، وهي متداولة لاى كثير من الشعراء لكنها

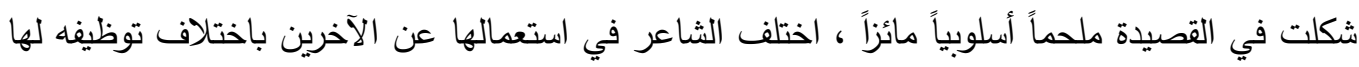

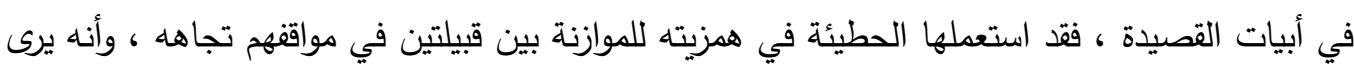

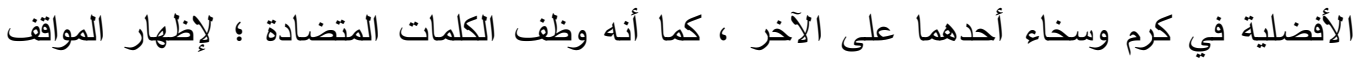

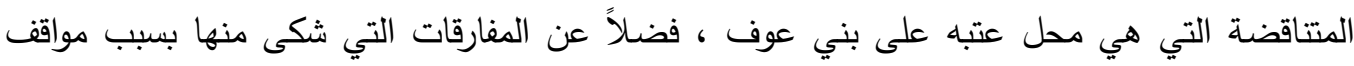

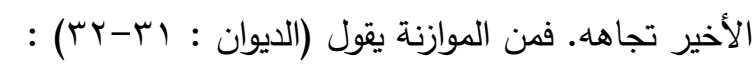

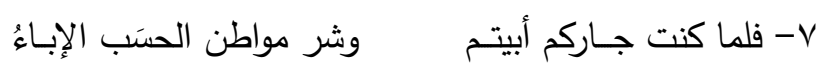

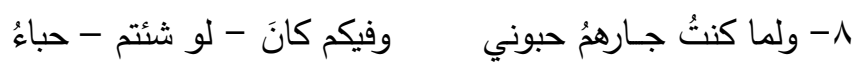

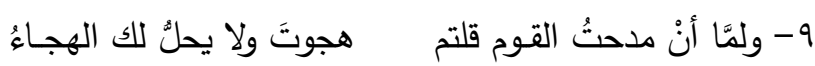
فالبيتان ( \ ، ^) وازن بهما الثاعر بين جيرة بني عوف وجيرة بني قريع ، فوسم بني عوف بالإباء

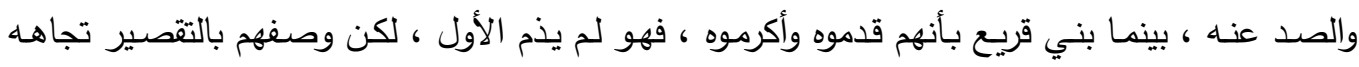

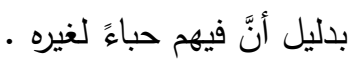

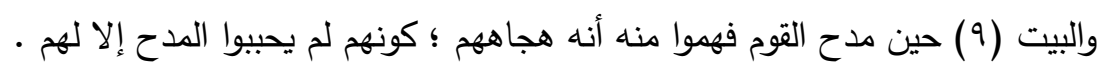
أما الموازنة في مواقف بني عوف المتضادة ، فيقول (الديوان : آب):

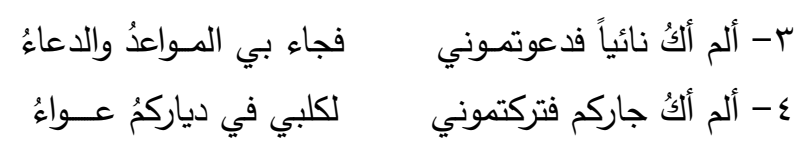

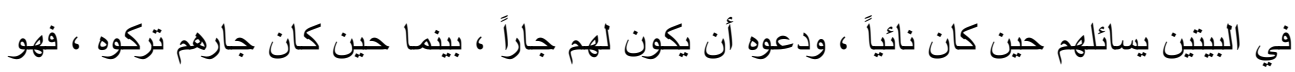

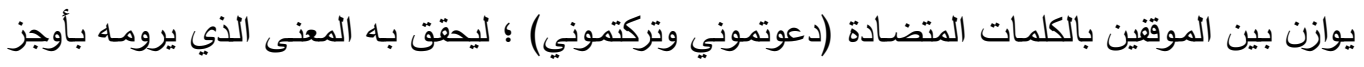

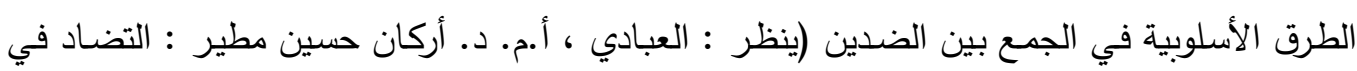

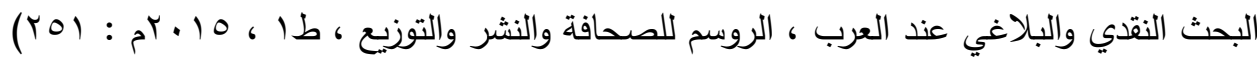

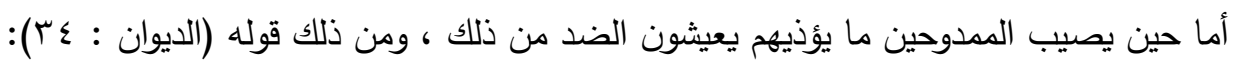

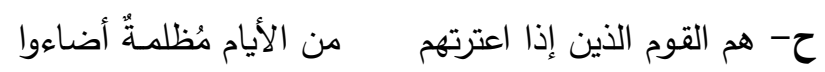
فحين تعتريهم مظلمة يضيئون ، وهذا التضاد يمنح النص دلالة دقيقة وموجزة ، وهو ملمح أسلوبي بارز تمتعت به القصيدة . 
العدد الثالث والأربعون

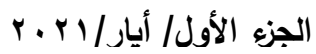

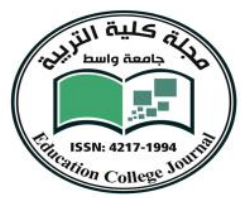

وحين يبين ما يعتريه من عناء يوازن بين ما يقع عليه به (الديوان : ك آT):

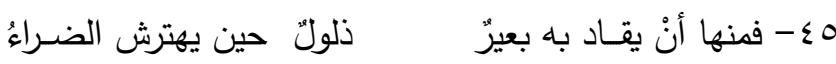

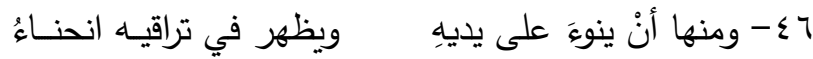

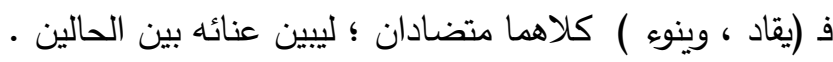

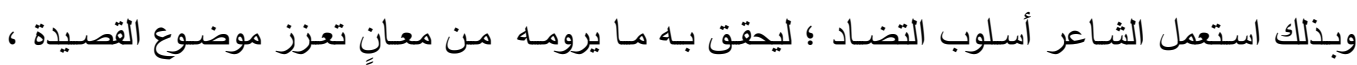
وتضفي على النص امتلاءات شعرية .

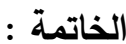

ما يلي أبرز النتائج التي توصلت إليها الدراسة :

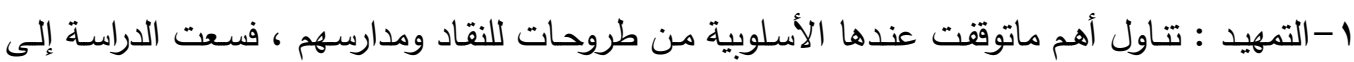

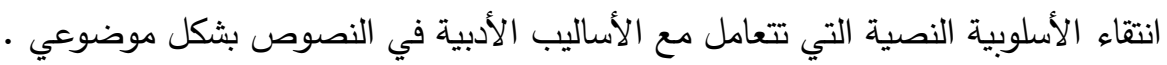
r-أما المبحث الأول تتاول أهم المهيمنات الأسلوبية في ما طرأ على موسيقاه من التفاتات فنية وظفهيا الثاعر في خدمة قصيدته ، فقد استعمل زحافي العصب والقطف ؛ ليعبر بهما عن شدة عاطفته مضيفاً

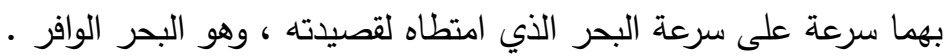

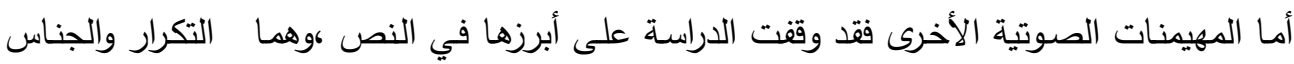

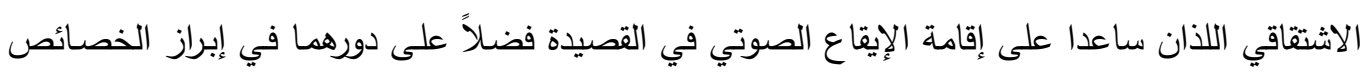
الأسلوبية وهما عمودان من أعدة الأسلوب في النص فعدًا من المهيمنات فيها.

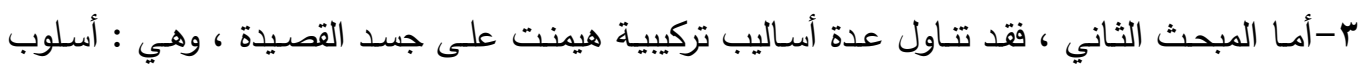

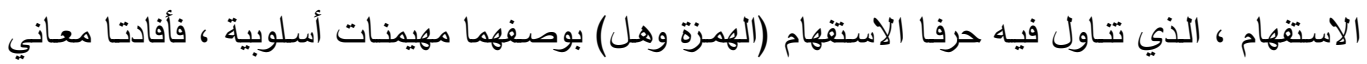

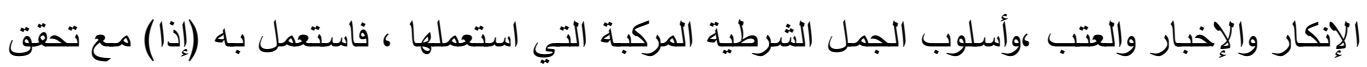

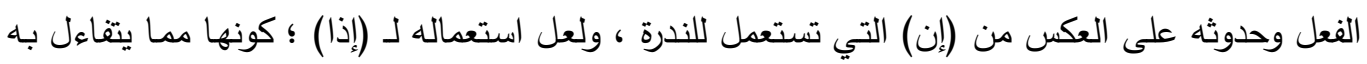

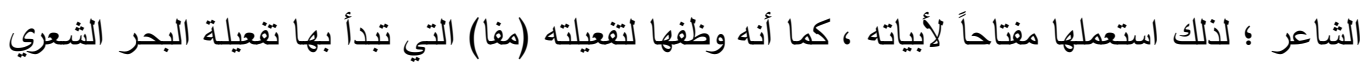

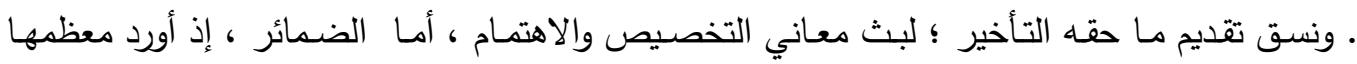

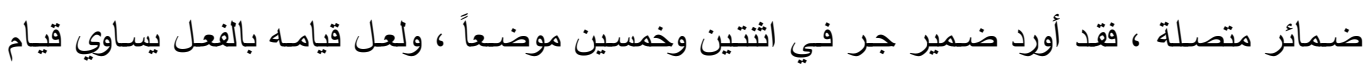

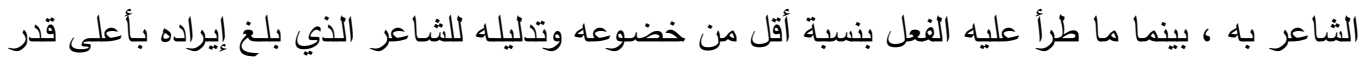

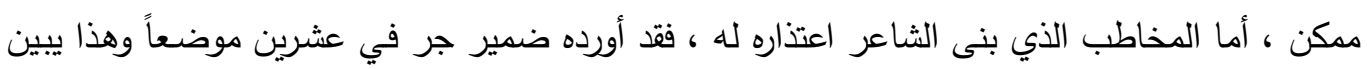


وقع تقصيره لهم إزاء ماقاموا بـه مـن أفعال حسب ورود ضـمير المخاطب تجـاههم ، ولعلـه في إيراد الضمائر دلالات بعيدة تؤكد استعماله لتلك الدلالات .

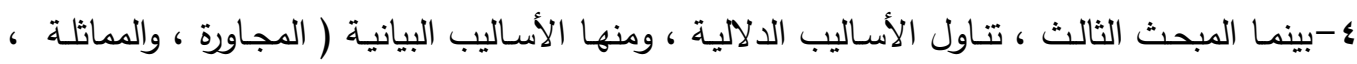

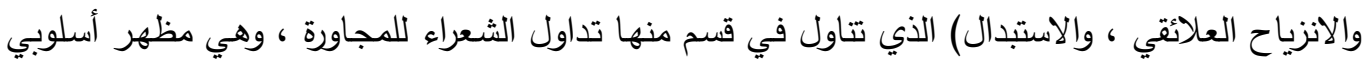

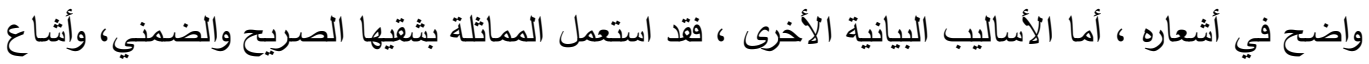

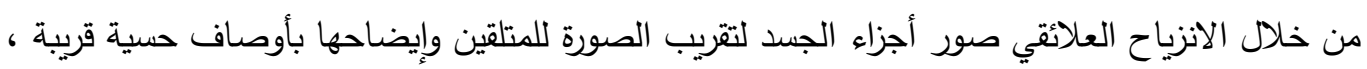

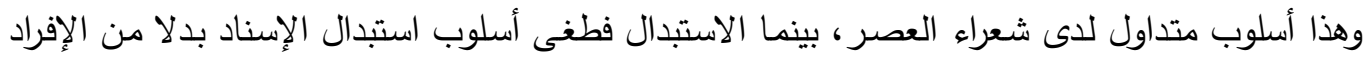

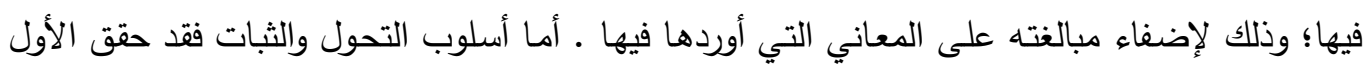

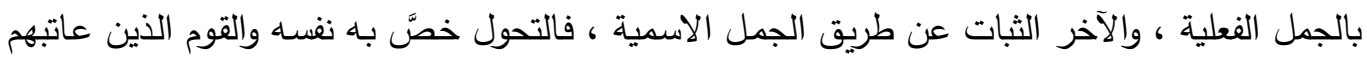

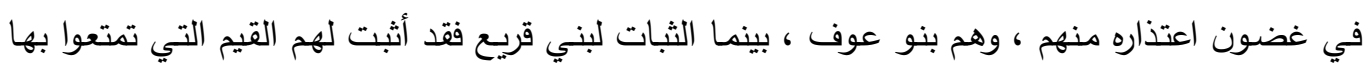

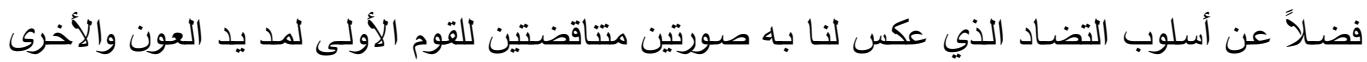

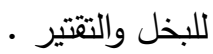


-ابن ذريل ، عدنان ، النص والأسلوبية ، منشورات اتحاد الكتاب العرب ، . . . ب م

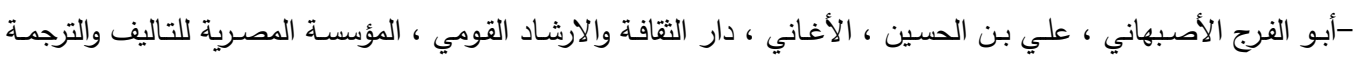

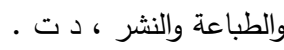

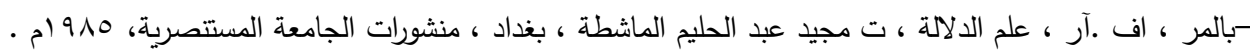

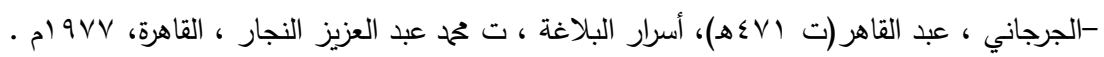

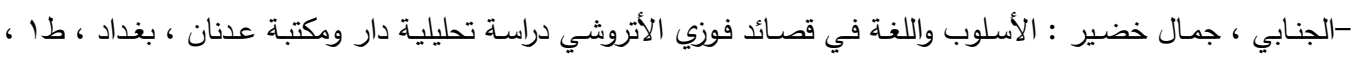
$\cdot{ }^{2}+1 \varepsilon$

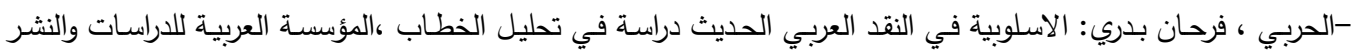

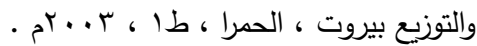

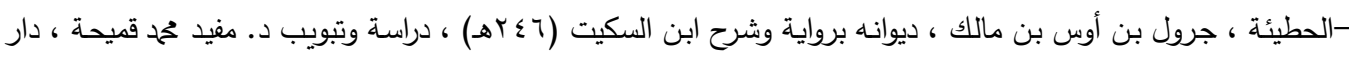

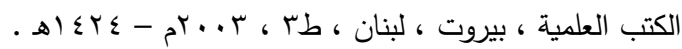

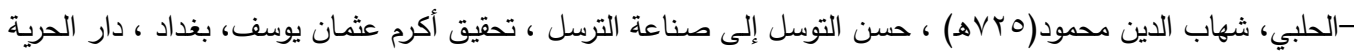

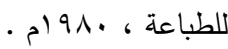
- حمودة ، عبد العزيز : المرايا المحدبة من البنيوية إلى التفكيك (سلسلة عالم المعرفة) ، المجلس الوطني للثقافة والفنون ،

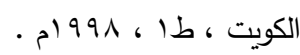
-دهمان ، أحمد علي : الصورة البلاغية عند عبد القاهر الجرجاني ، منهجاً وتطبيقاً ، دار طلاس للدراسات والترجمة والنشر ،

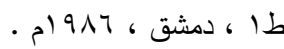

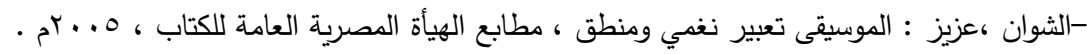

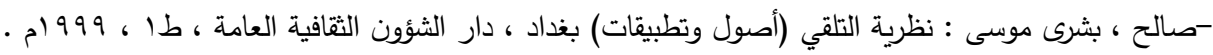

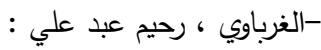

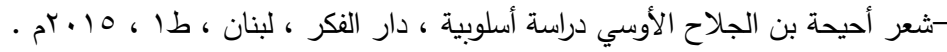

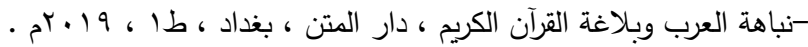

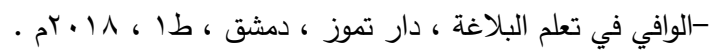

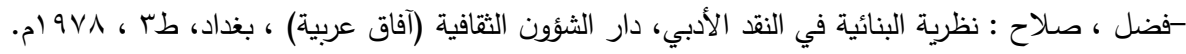

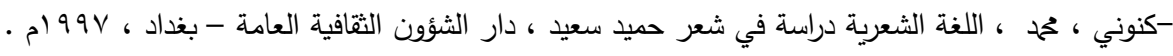

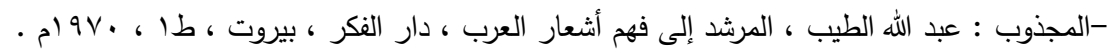

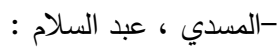

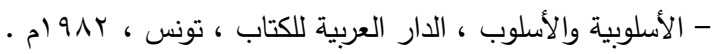

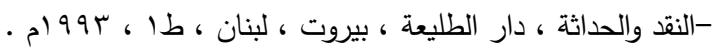

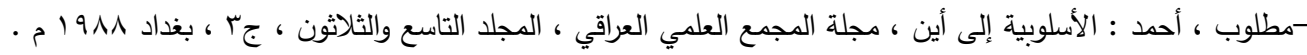

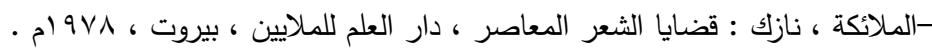

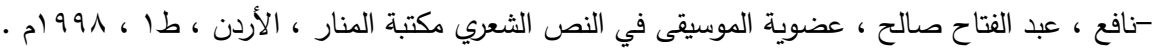




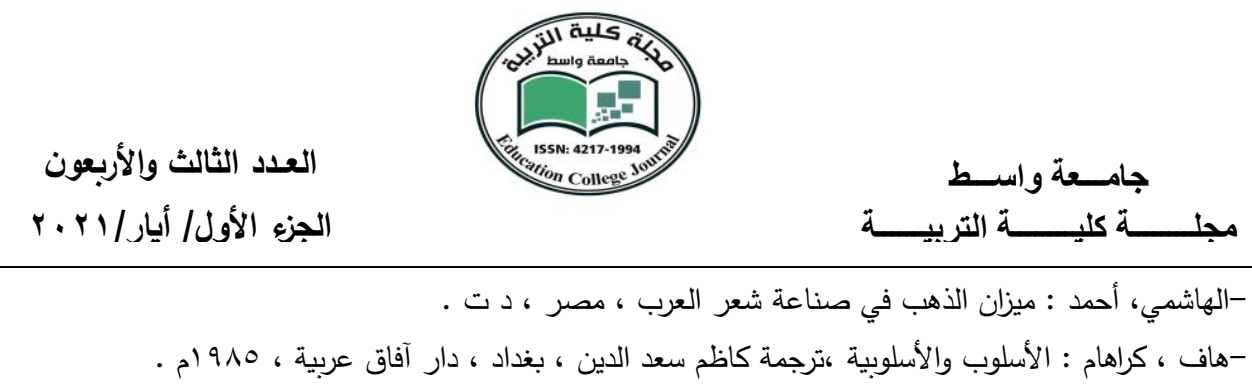

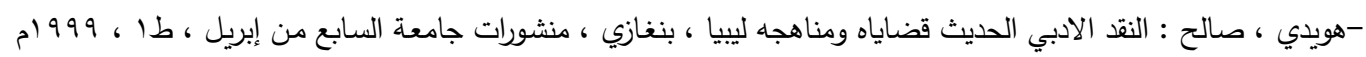

